\title{
Corporate Social Responsibility and Human Resource Management: Towards Sustainable Business Organizations
}

\author{
Juan Herrera * (D) and Carlos de las Heras-Rosas *(D) \\ Department of Economics and Business Administration, Universidad de Málaga, 29071 Málaga, Spain \\ * Correspondence: juanherrera@uma.es (J.H.); chr@uma.es (C.d.1.H.-R.)
}

Received: 29 December 2019; Accepted: 20 January 2020; Published: 22 January 2020

\begin{abstract}
Today's organizations are immersed in a global market, where any detail can provide a competitive advantage over rival companies and condition their sustainability. Corporate Social Responsibility and Human Resource Management have become very powerful tools within companies. However, the potential, development, and measurement of Corporate Social Responsibility (CSR) and Human Resource Management (HRM) have not been sufficiently explored. The literature has developed multiple case studies on CSR and HRM and has studied the combination of both factors and their link to economic, environmental, and social sustainability, but has not yet found a solid basis from which to address the new functionality of CSR, HRM, and sustainable business management. This work aims to investigate trends in scientific production related to Corporate Social Responsibility and Human Resource Management. Bibliometric techniques and SciMAT software have been used for this purpose. A total of 314 articles from Web of Science (WOS) indexed journals were analyzed. The results obtained confirm that the interest in the study of these concepts has grown exponentially in the last decade. It should be noted that the definitions of CSR and HRM, and even the relationship between the two, continue to be subject to multiple interpretations. The contribution of this work lies in the fact that, through the longitudinal analysis carried out, light is shed on the groups of issues that emerge with special projection, such as green-management, stakeholders, commitment, competitive-advantage, satisfaction, performance, sustainability, or research-methods-analysis, and which must continue to be explored in order to respond to the demands that business organizations have in this respect, and to help the total integration of the different approaches related to CSR and HRM.
\end{abstract}

Keywords: CSR; HRM; SR-HRM; sustainability; green-management; SciMAT

\section{Introduction}

Research on Corporate Social Responsibility (CSR) and Human Resource Management (HRM) has experienced an unprecedented boom in the last decade. This increase has not only come from researchers and academics, and the business world has also taken a deep interest in this field [1].

In the literature analyzed, there is no consensus on a definition of CSR [2,3]. In fact, it can be said that CSR is indeterminate, dimensionless, regional, and cultural. The CSR has different meanings depending on where we are, the person interpreting it, or even the company practicing it [4]. The concept of CSR has developed over time [5], and varies by country and cultural background [6]. In fact, Dahlsrud in 2008 [7] published a review article where he brought together 37 different definitions of CSR, concluding that although there is some agreement regarding the identification of the dimensions of CSR, which would be: social, economic, and environmental, it is difficult to develop an impartial and global vision of CSR, mainly due to the specific factors of the context and how each company 
relates to its stakeholders [8]. One of the most frequently cited definitions of CSR is Carrol's statement: "the social responsibility of business encompasses the economic, legal, ethical and discretionary expectations that society has of organizations at a given point in time" [9,10].

With regard to Human Resource Management, there is also a wide range of definitions and views. The first important step in this regard was to clearly distinguish HRM as a function or process from the general management activities of the organizations [11]. The concept of HRM has been modeled over time and, as with CSR, varies by region. The purposes and definitions of HRM have been analyzed from multiple points of view, usually based on other disciplines [12,13]. The study of HRM has been based on ideological frameworks (Unitarianism, pluralism, radicalism) [14], from the perspective of power, control from structuralist or humanist perspectives $[15,16]$, or from the point of view of the stakeholders and their relationship with the company [17]. However, the very syntax of HRM (Human Resource Management) already includes the conception of humans as company resources [18]. Mueller and Carter in 2005 [19] define HRM as "Institutions, discourses and practices focused on the management of people within an employment relationship enacted through networks comprising multiple public and private actors".

Both the CSR and the HRM are described and analyzed from different perspectives, usually linked to the objective of the research in progress, or the discipline from which the study is carried out. One of the common points of CSR and HRM in the company is sustainability. Sustainability has been mainly related to the environmental dimension [20], although another stream of research adopts the broader definition offered by the World Commission on Economic Development (WECD) [21], which also considers the economic and social dimensions [22]. The literature questions in many cases the extent to which economic growth and sustainability can be reconciled $[23,24]$, or how profitability and sustainability of human and social resources can be integrated into an organization's performance [25]. The role of human resource management within sustainability remains a relatively underdeveloped area of research [26], although numerous papers have appeared in recent years as overviewed in this manuscript. Gond et al. in 2011 [27] indicate how HR managers in companies tend to delegate CSR and sustainability issues to other members of the organization. The development of research on corporate sustainability is converging towards a common point, where a vision is obtained that balances social and environmental concerns with business operations and relationships with all stakeholders $[8,28]$. In this sense Van Marrewijk in 2003 (p. 102) [8] defines CSR as: "company activities—voluntary by definition-demonstrating the inclusion of social and environmental concerns in business operations and in interactions with stakeholders".

These three figures, CSR, HRM, and Sustainability have evolved and interacted over time, linked by a series of binding elements, such as stakeholders or green-management. This relationship has generated a political problem within organizations regarding the definition of competencies and functionality between RSC, HRM, and sustainable management, where a balance of power has become necessary [27,29]. Gond and collaborators [27] identify up to three configurations of how CSR and HRM interact with each other, with different degrees of balance between them and with respect to Sustainability.

Companies have responded to the new social demands of their stakeholders with the implementation of CSR actions, which include environmental and social activities that go beyond the mere economic interests that traditionally characterize companies. Porter and Kramer [30] describe a new scenario where pure economic interests and social benefits converge in a single space. CSR and HRM can give a company a competitive advantage by aligning its practices towards business and environmental sustainability.

The contribution of HR to the development of sustainable business organizations has been analyzed on multiple occasions [26], including their assistance to human sustainability itself as defined by Ehnert and Harry in 2012 [31]. By contrast, studies that address how business practices influence workers from an individual approach have not had as much research experience $[29,32,33]$. 
Most research focuses on the results obtained within the organization, leaving the management of sustainable human resources outside it [10].

It is clear that the CSR and HRM are partners in the current policy of the organizations, where sustainability stands as a moderating component of this relationship. However, we could ask ourselves if the relationship between these three elements is the result of modern management in organizations, or if human resource management has positioned itself as an effective tool to promote sustainable Corporate Social Responsibility. Technological developments, competition, and globalization have caused drastic changes within and between organizations, modifying, among other things, human resource management strategy [34]. As Guerci and Pedrini [35] point out, human resources represent a key element in driving change towards the sustainability of organizations, through the implementation of sustainable practices, as well as meeting the needs of all stakeholders.

The research landscape on this topic is in full swing, although the academic and business motivations that are generating it lack a certain consensus. The key questions in this research were: how has research on CSR and HRM evolved and what links them to sustainable management in the company, and what other factors come into play in the CSR-HRM-Sustainability relationship?

The purpose of this document is to provide an overview of research addressing CSR, HRM, and sustainable management, and the interaction between them. This is done in three distinct phases. The first comprises an exhaustive review of the definitions and research flows on this subject. Subsequently, a quantitative analysis is carried out using indicators of CSR-HRM activity, which shows which authors and publications, among other data, are the most prolific in recent decades. Finally, a longitudinal analysis divided into three stages will allow us to discover how these concepts have evolved and what relationship they show between themselves and with respect to other factors that are gaining importance in recent times.

\section{Methods}

The aim of this work is to understand the trends in scientific production on Corporate Social Responsibility and Human Resources Management. The proposed research is based on the bibliometric analysis of the scientific literature using the article as the basic unit. A bibliometric analysis examines bibliographic material from an objective and quantitative perspective that is useful for organizing information within a field specification [36]; therefore, a metric analysis of the literature allows for the analysis of the details of the main research topics within a domain and the relationships at the micro level, generating useful information for researchers evaluating the scientific activity $[37,38]$.

In the process of analysis, a detailed detail will be made in two differentiated sets-activity indicators and relationship indicators. The observation and study of the selected articles will reveal the evolution of research related to CSR and HRM. Likewise, the information extracted from the literature, such as the year of publication of the articles, authors, citations, origin, impact indices, and other characteristics will allow us to make a complete outline of what scientific production in this field has meant.

\subsection{Materials}

The analysis of publications has been carried out in the Web of Science database in October 2019 [39]. The analysis was carried out in the Web of Science database for two main reasons. The journals indexed in the Web of Science database present one of the highest quality standards of current scientific production. On the other hand, documents from other databases could have been included, but this poses a methodological drawback for some phases of our research. Impact indices and other metrics often differ between the various databases, so a comparison between articles from different sources may generate errors of appreciation. We believe that focusing on a single database, such as Web of Science, provides quality data and information for conducting research of this type. As for the adjustment of the research criteria, the combined expressions "Corporate Social Responsibility" or "CSR" and "Human Resource Management" or "HRM" or "Socially Responsible Human Resources 
Management" or "SR-HRM" have been used as search parameters. It has been restricted to the Science Citation Index Expanded (SCI-EXPANDED) and Social Sciences Citation Index (SSCI). In both cases the year of publication is not limited. The interest of the research is to find coincidences in articles on CSR and HRM, in the title as well as in the abstract and the keywords of the articles available in the database. "SR-HRM" was included in the search, in order to also include those documents analyzing human resources management from a socially responsible perspective as a result of the permeability of CSR application in organizations. On the other hand, due to the multidisciplinary approach given to this subject, the search has not been restricted to the different categories arranged in the Web of Science (WOS) database.

The configuration described above selected a total of 336 items in this source. To identify the most relevant research, in order to apply a first filter on relevance to the subject matter, the two authors independently read the titles and abstracts of the 336 articles. Both authors agreed on the qualification "suitable" for a total of 302 articles. The 34 articles that did not pass the first review were analyzed further, and it was concluded that 22 of them were not suitable for this bibliometric analysis. Therefore, a total of 314 items were selected. In the analysis of publications using bibliometric techniques, it is usual to select the most cited articles from the entire sample obtained. In this case, it was decided to include the 314 articles that met the search parameters. This means that recent documents that may not yet have reached their full impact are not discarded.

In order to obtain a global and temporal perspective of the evolution of the subject, on the one hand a descriptive statistical analysis was carried out where the indicators of activity of the literature are detailed, and on the other hand, to know the state of the research and its evolution, longitudinal and strategic maps and thematic networks were constructed.

In order to study research on a subject in a longitudinal way, it is necessary to create periods that can contain the set of publications to be analyzed. For this work, the criterion taken has been a compromise between the length of the period and the number of publications. In this sense, it was estimated that periods of 5 years would favor the analysis. The distribution has been done starting from the year of the last document published (2019) backwards; however, due to the low production of publications between 2009 and 1993, it was decided to create a single block containing the set of documents between those dates. The distribution, therefore, was in three periods and as follows: 1993-2009, 2010-2014, and 2015-2019.

\subsection{Software}

The research was supported by the computer tool SciMAT. This software was developed by SECABA, a research group from the University of Granada (Cobo, López-Herrera, Herrera-Viedma, and Herrera, 2012) [40]. SciMAT allows the construction of longitudinal and strategic maps and thematic networks that allow one to see in a chronological way what was the thematic evolution of the literature under study. The following configuration of SciMAT has been carried out for the analysis: the author's keywords and the keywords from the source were used as the unit of analysis, and the co-occurrences were used to build the networks. The equivalence index was used as a measure of similarity to normalize the network, and a single center-clustering algorithm was used to create the scientific map of topics and their networks.

A strategy map is divided into four quadrants (Figure 1). The motor themes are in the upper right quadrant, the peripheral themes are in the upper left quadrant, the emerging themes are in the lower left quadrant, and the basic themes are in the lower right quadrant [40]. With respect to the former, they represent the motor themes of the specialty, because they present a strong centrality and a high density and they are well developed and are important for the construction of the scientific field; on the other hand, they are very externally related to concepts applicable to other themes. With regard to peripheral issues, they have well-developed internal links, are highly specialized, and are of marginal importance in the scientific field. Emerging or decadent themes have a very low density and centrality and are therefore very underdeveloped and marginal. Finally, the basic themes are important for 
the scientific field, but they are not sufficiently developed and are cross-cutting and generic themes. Therefore, they are basic themes of the scientific field. The third dimension in the strategic map is included through the theme spheres, where its volume can represent different bibliometric indicators, such as the number of documents associated with a theme, the number of citations received by the documents associated with each theme, or the H-Index of the theme.

From each cluster or main theme, a network is formed which is called a thematic network (Figure 1). This is formed through the interconnection of keywords based on the documents associated with each theme. Each thematic network is assigned the documents that share some keywords with the network. Two types of networks can be considered: main documents and secondary documents. A main document will be one that contains at least two keywords from the thematic network, and a secondary document will be a document that has at least one keyword associated with the thematic network, so that both primary and secondary documents can belong to more than one thematic network [41]. In this work, both quantitative (documents) and qualitative (H-index) analyses were carried out on the network of primary documents.
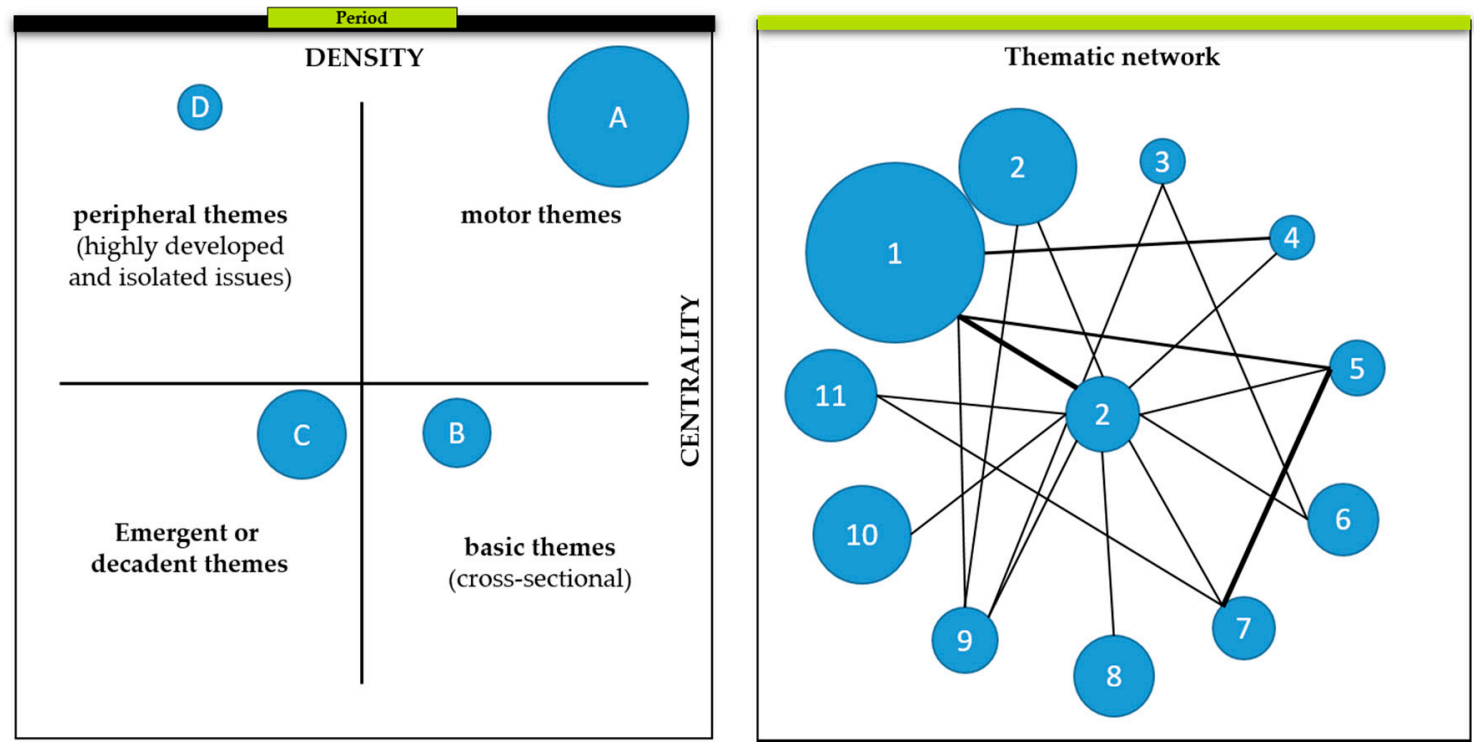

Figure 1. Example of a strategic map and thematic network. A, B, C and D represent different clusters. $1,2,3, \ldots, 11$ represent members of the thematic network. Source: Prepared by the authors, based on Cobo (2011) [41].

\section{Results}

\subsection{Activity Indicators in the CSR and HRM Literature}

The number of annual publications linking CSR and HRM has increased significantly. The sample analyzed consists of 314 articles, the first of which appeared in 1993, "Corporate social-responsibility and worker skills - an examination of corporate responses to work place illiteracy contract" published by Anderson in the Journal of Business Ethics [42], where it is shown how corporate philosophies were almost independent of organizational variables. The first research of relevance due to the number of citations it has (270), is that carried out by Albinger and Freeman in 2000 [43], also published in the Journal of Business Ethics. This journal is one of the pioneers and remains the most productive in this field, contributing 38 articles to our collection, with an almost uninterrupted rhythm since 2000.

As can be seen in Figure 2, from 2007 onwards the scientific production related to CSR and HRM started a constant increase, reaching more than 60 articles in 2019. Based on the temporal distribution described in the methodology used in this study, we analyze the literature from the first period (1993-2009), which is characterized by approaches more closely related to business ethics [42,44], 
and where CSR is beginning to be addressed by researchers through analysis and case studies [45-47]. In this period, the connection between CSR and HRM has not yet been strongly developed, although important research has appeared that asks what effect responsible/sustainable management of the company has on human resources and vice versa [48-53]. The second period (2010-2014) describes an uneven growth in CSR and HRM publications, although in five years the number of publications has increased from 6 to 22 per year. In this second stage we find the first manuscripts that relate CSR to HRM and the organization's business performance [27,54-59]. The third period (2015-2019) presents the highest growth of the studied sample. Out of 20 articles registered in 2015, 62 were registered in 2019, a year that has not yet ended at the time of writing.

The issues addressed during this very productive period are multiple, although certain key terms appear: green management; the impact on companies of CSR practices, where methods of analysis are sought to measure performance; and the impact of CSR and HRM on employees and other stakeholders. Research deals with how to generate the right balance between economic, social, and environmental objectives in an organization [60-65], the importance of internal and external stakeholders [66-68], green management of human resources [65,69-73], or how to adequately measure the impact of CSR, HRM, and sustainability on business practices and the company's image [74-79].

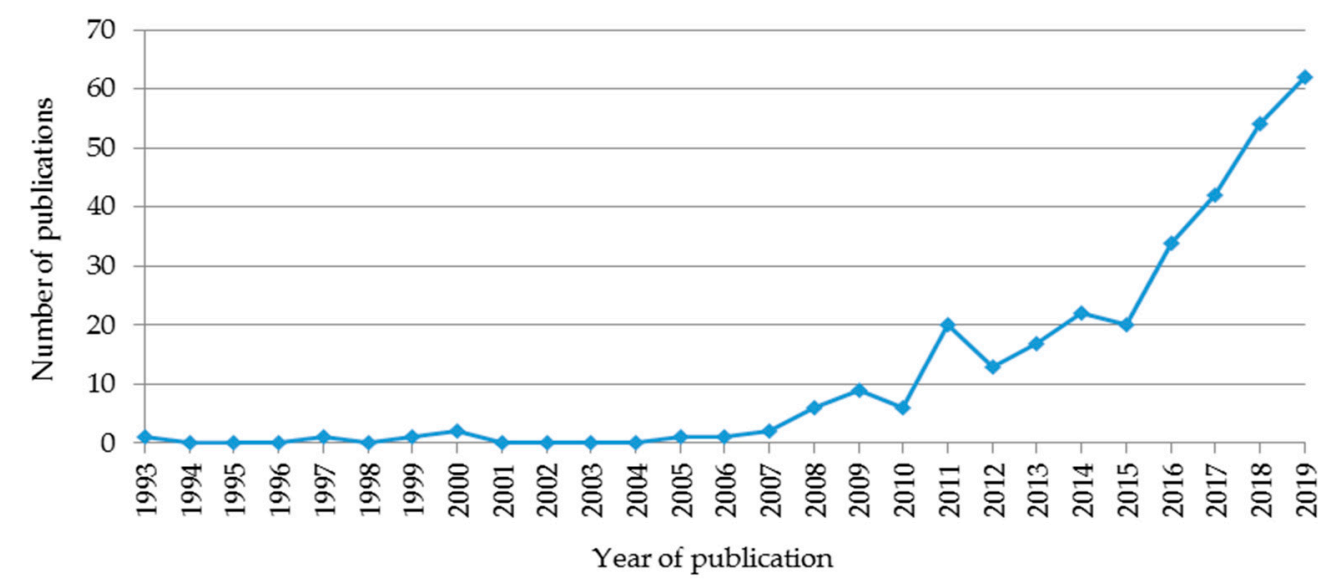

Figure 2. Publications over time on Corporate Social Responsibility (CSR) and Human Resource Management $(\mathrm{HRM})(n=314)$. Source: Prepared by the authors on the basis of Web of Science (WOS) data.

Of the 314 articles analyzed, if we take into account the affiliation of the first author of the chosen research, researchers from the United States of America are the ones that publish the most on this subject with 53 articles, followed by researchers from Spain with 35, China with 29, Australia with 23, and England with 21 (these are the ones that exceed twenty). They are followed by Italy (13), France (11), Germany (11), Canada (10), and Poland (10). The rest of the articles analyzed are distributed among 42 other countries.

In the compilation and counting of articles per author, there are groups of researchers who have jointly published a high number of articles, although the research production with respect to this subject is quite distributed. In total, the 314 articles in the selected sample include 775 authors from 52 countries. The Web of Science (WOS) database scores and publishes the Hirsch Index, or H-index, of each author, which corresponds to the number of publications and the times he or she has been cited. The following table shows the authors with the highest number of publications and their H-index (Table 1). 
Table 1. Authors who have published three or more articles on CSR-HRM.

\begin{tabular}{cccc}
\hline Author & Number of Articles & Year of Publication Last Article & H-Index in WOS \\
\hline Lopez-Fernandez, M & 7 & 2019 & 6 \\
Shen, J & 7 & 2019 & 14 \\
Romero-Fernandez, PM & 5 & 2019 & 2 \\
Guerci, M & 5 & 2018 & 12 \\
Martinez-Brush, J & 4 & 2019 & 4 \\
Aguinis, H & 4 & 2019 & 47 \\
Li, J & 3 & 2019 & 12 \\
Mangla, SK & 3 & 2019 & 21 \\
Luthra, S & 3 & 2019 & 20 \\
Baum, T & 3 & 2019 & 21 \\
Newman, A & 3 & 2019 & 23 \\
Cooke, FL & 3 & 2019 & 11 \\
Longoni, A & 3 & 2018 & 8 \\
Zientara, P & 3 & 2017 & 18 \\
Swaen, V & 3 & 2017 & 22 \\
Wagner, M & 3 & 2016 & \\
\hline
\end{tabular}

Source: Prepared by the authors on the basis of WOS data.

The most frequently cited authors per article are not represented in the above list, as their production in this field has not been as numerous, although it has been referenced on many occasions. Fulmer and Gelfand [80] with the manuscript "At What Level (and in Whom) We Trust: Trust Across Multiple Organizational Levels" cited on 475 occasions; and the research of De Stefano, Bagdadli, and Camuffo [10], who presented in 2018 "The HR role in corporate social responsibility and sustainability: A boundary-shifting literature review" with 218 citations.

With respect to the journals with the greatest presence in CSR and HRM research, it can be seen that the set of 314 articles studied in this work from 1993 to 2019 are distributed in 122 different journals, highlighting the Journal of Business Ethics with 38 publications and Sustainability with 30 published researches.

The Impact Factor percentile of the main journals in this bibliometric is usually located in the first and second quartiles. Table 2 lists the journals with the greatest impact on CSR and HRM studies. The WOS database has been analyzed through its Science Citation Index Expanded (SCI-EXPANDED) and Social Sciences Citation Index (SSCI) families, where the quartiles are shown with respect to the rest of the publications in each thematic category and each database. There are cases where some journals present a different classification according to different areas of knowledge, in this case the one corresponding to the subject matter at hand has been chosen.

Table 2. Journals on CSR and HRM.

\begin{tabular}{|c|c|c|c|c|c|c|c|}
\hline N. & Journal & Q1 & Q2 & Q3 & Q4 & Total Items & $\%$ \\
\hline 2 & Sustainability & & $X$ & & & 30 & $9.6 \%$ \\
\hline 4 & International Journal of Human Resource Management & & $X$ & & & 17 & $5.4 \%$ \\
\hline 5 & Human Resource Management & & $X$ & & & 10 & $3.2 \%$ \\
\hline 6 & Personnel Review & & $X$ & & $X$ & 8 & $2.5 \%$ \\
\hline 9 & Business and Society & $X$ & & & & 5 & $1.6 \%$ \\
\hline 10 & Sustainability Accounting Management and Policy Journal & & & $X$ & & 4 & $1.3 \%$ \\
\hline 11 & Management Decision & & & $X$ & & 4 & $1.3 \%$ \\
\hline 12 & Inzinerine Ekonomika-Engineering Economics & & & & $X$ & 4 & $1.3 \%$ \\
\hline 13 & Journal of Management & $X$ & & & & 4 & $1.3 \%$ \\
\hline
\end{tabular}

Source: Prepared by the authors on the basis of WOS data. 
The Journal of Business Ethics, whose volume 1 appeared in 1980, is the most active in this field with 38 articles since 1993, and with a continuous production until these days. The second publication with 30 articles is Sustainability, which appeared in 2009. In Table 3, and using the same numbering and order as Table 2, we show again the journals that have at least 4 publications within the selection made in this article and their activity by year.

Table 3. Annual journal activity in articles on CSR and HRM. Darker background color means more journal activity in this area.

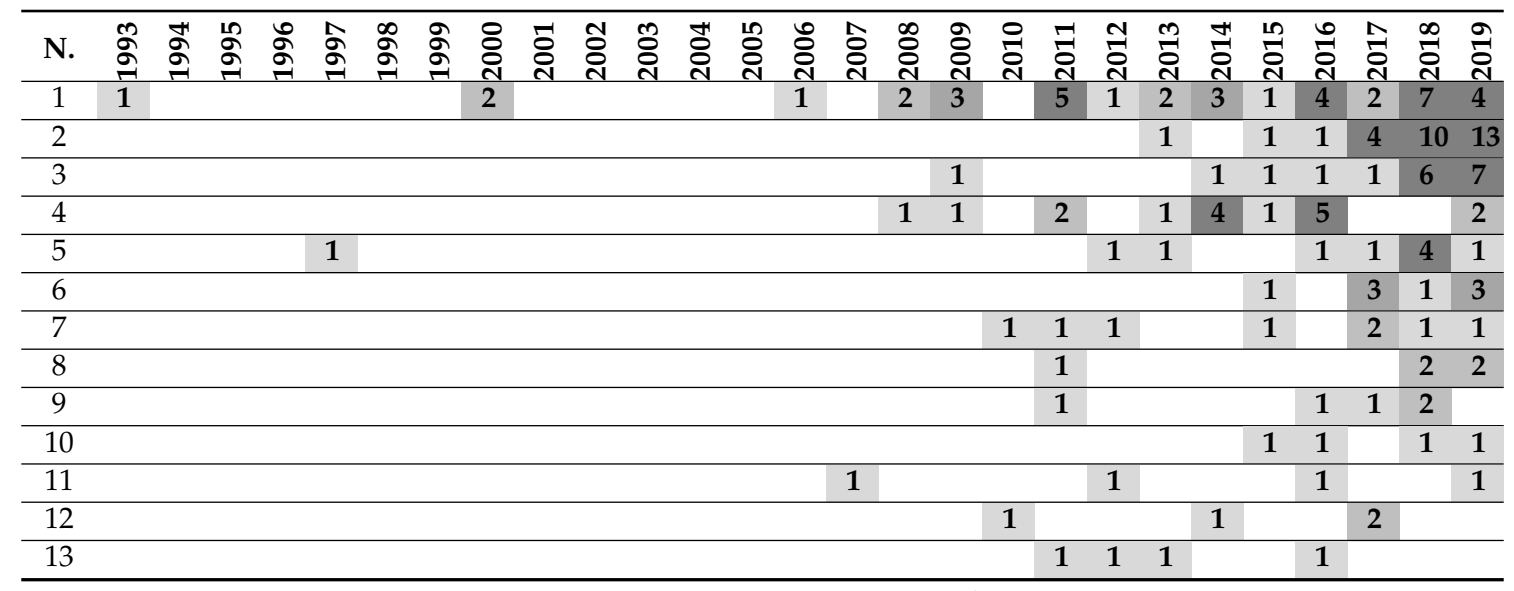

Source: Prepared by the authors on the basis of WOS data.

The Journal of Business Ethics and Sustainability publications represent more than 20\% of the articles in the sample. The rest of the journals do not have a large number of works on this subject, which indicates that few journals have specialized specifically in this area. It also gives an idea of how this subject is represented from multidisciplinary approaches and that, although the search in certain areas of knowledge is limited, the study of the CSR and the HRM admits points of view from various disciplines.

\subsection{Content Analysis}

\subsubsection{Evolution of Keywords}

In order to analyze the conceptual and thematic evolution of the literature related to CSR and HRM, we first analyze how keywords have evolved, their overlapping, continuity and discontinuity in a chronological way, taking into account the previously delimited periods. As defined in the methodology, a compromise between the length of the period and the number of publications was used for the delimitation of the periods. However, due to the fact that in recent years the growth of literature on this subject has been so high, the number of documents from this last period is very high, leaving the distribution in terms of documents unbalanced, which has had to be subjected to the necessary weighting filters which the software provides, and which will allow a rigorous analysis to be made. Thus, the first period (1993-2009) contains 24 documents, the second (2010-2014) 78 documents, and the last (2015-2019) 212 documents (Table 4).

Table 4. Periods and number of documents per period.

\begin{tabular}{ccc}
\hline NO. & Period & N. of Documents \\
\hline 1 & $1993-2009$ & 24 \\
2 & $2010-2014$ & 78 \\
3 & $2015-2019$ & 212 \\
\hline
\end{tabular}

Source: Prepared by the authors on the basis of SciMAT data. 
For the analysis of the evolution of keywords in the area we use the methodology of Price and Gürsey [81]. The circles constitute the established periods and inside them they include the number of keywords of the period. The arrows between periods represent the shared keywords and, in brackets, the stability index or overlap fraction. On the other hand, in each period, the incoming and outgoing arrows report the new keywords and the keywords that have not been used in the following period respectively. Thus we can see in Figure 3 how in each period new keywords are incorporated and others are not used in the next period. A high number of keywords was observed, which gives an idea of the diversity of adjacent topics dealt with by the central core of this study. However, the stability index remained between 0.51 and 0.57 , which shows a high and growing strengthening of vocabulary by the scientific community when describing the published documents [40]. As for the analysis of the periods, the number of keywords is closely related to the number of publications, so the last period (2015-2019) accumulates the maximum number of keywords with 582.

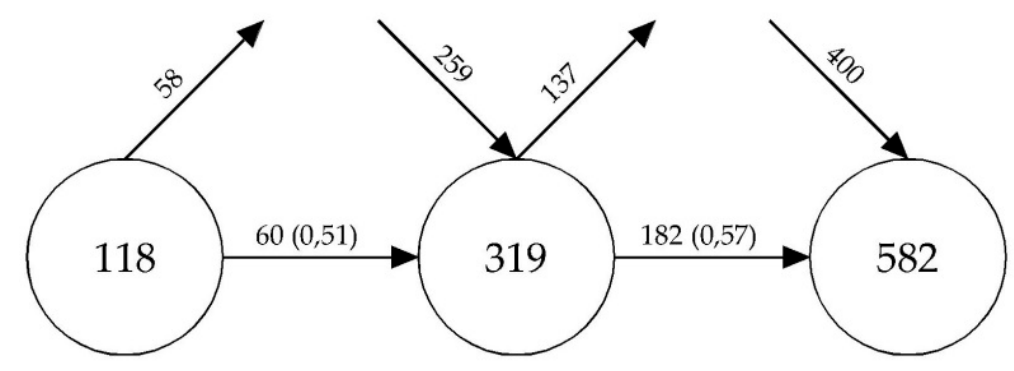

Figure 3. Keywords between periods. Source: Prepared by the authors on the basis of SciMAT data.

\subsubsection{Longitudinal Analysis}

After analyzing the progress of keywords, the research focused on how the literature has evolved in relation to CSR and HRM as seen in Figure 4.

Period 1993-2009

In this period, taking into account its centrality, the predominant theme is Business-Ethics. This is a driving issue that becomes less relevant in subsequent periods in favor of CSR, which will take the lead in terms of centrality and density until 2019 (Figure 4). Business-Ethics, with an H-Index of 13 , has a relatively low number of documents (16) compared to CSR (77 and 206, first and second periods, respectively). However, although it has the benefit of time, its number of citations (1024) compared to CSR (3277 and 1540, first and second periods, respectively) is relevant and favorable proportionally (Tables 5-7). The most frequently cited works on this subject are published in the Journal of Business Ethics by the authors Albinger and Freeman (2000) [43]; Collins (2000) [82]; Cornelius, Todres, Janjuha-Jivraj, Woods, and Wallace (2008) [83]; and Holder-Webb, Cohen, Nath, and Wood (2009) [84], with a cumulative 670 citations (65.4\% of the total). The existence of a positive relationship between employers performing CSR and the capacity to attract more qualified employees, as well as the impact of the size and typology of the companies for the implementation of CSR policies within them, are some of the issues investigated.

As for Business, it occupies a central position in the matrix of the strategic map, which means that it has an equidistant centrality and density; therefore, it is difficult to glimpse the projection of such a theme. The number of papers is 7, with a total of 343 citations and an H-Index of 7. The most cited authors in this area are Vuontisjarvi (2006) [47] and Bohdanowicz and Zientara (2008) [85], 99 and 83 citations, respectively. In the case of the first paper, it deals with the first steps of the CSR in Finland, demonstrating the lack of awareness and information about it. The second publication is a case study of CSR in hospitality companies, highlighting the implications of CSR for human resource management and support for local communities and the promotion of environmental sustainability. 


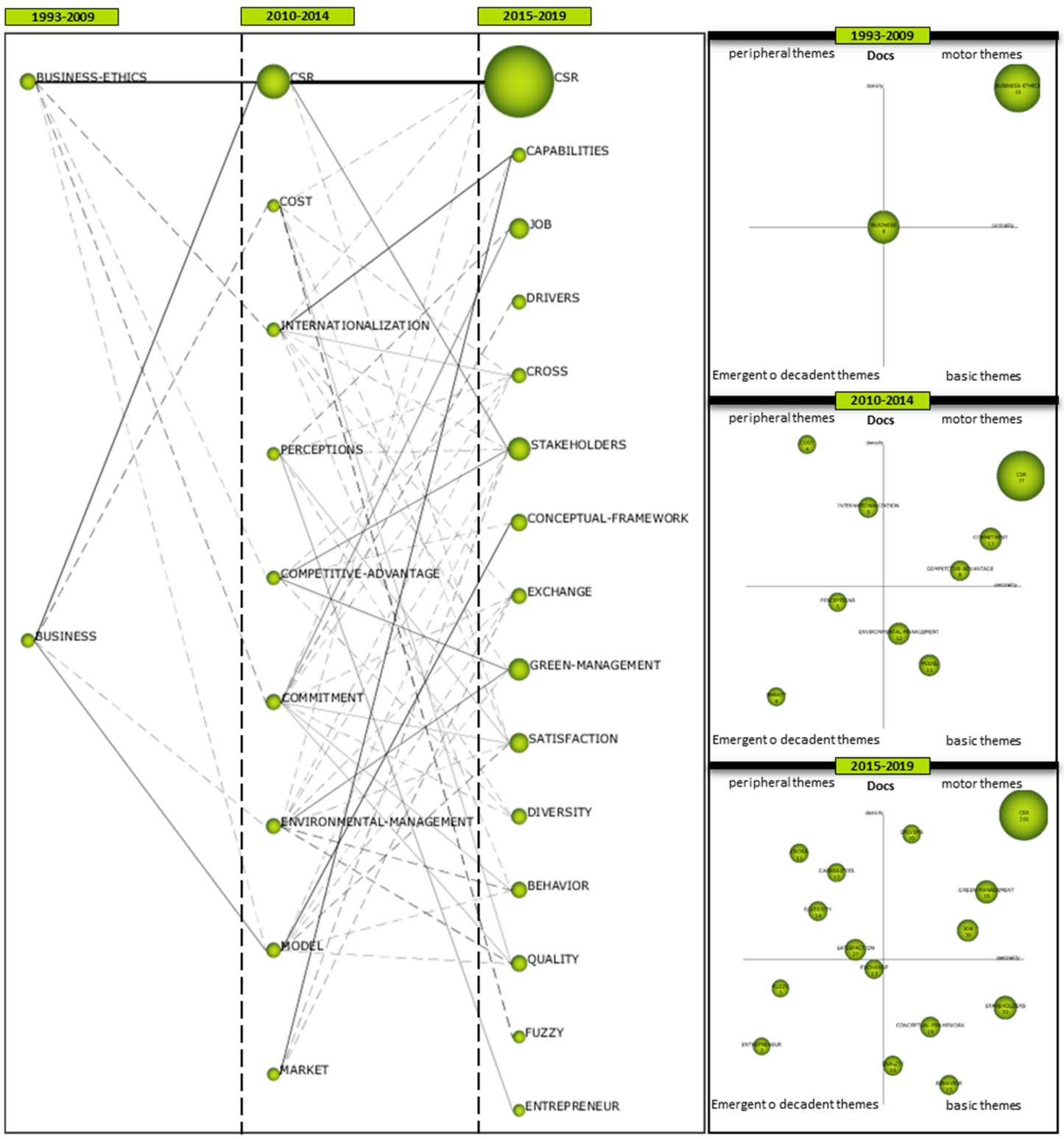

Figure 4. Evolution of the themes of the primary documents. The three strategic maps represented on the right of the figure are included in Appendix A of this document at a larger size. Source: Prepared by the authors on the basis of SciMAT data.

Table 5. Cluster period 1993-2009.

\begin{tabular}{cccccccc}
\hline Name & Centrality & Centrality Range & Density & Density Range & Documents & Citations & H-Index \\
\hline Business-Ethics & 78.09 & 1.00 & 64.33 & 1.00 & 16 & 1024 & 13 \\
Business & 71.46 & 0.50 & 37.25 & 0.50 & 8 & 343 & 7 \\
\hline
\end{tabular}

Source: Prepared by the authors on the basis of SciMAT data.

Period 2010-2014

In the second of the periods designed in this work, due to the increase in the number of documents (from 24 to 78) (Table 4), the increase in the number of keywords incorporated (259), (Figure 3) and, above all, the density in the network of these has led to a greater proliferation of clusters or themes. The driving themes are CSR, Commitment, and Competitive-Advantage, with 77, 33, and 8 documents, respectively. In this period, it is also necessary to highlight the issue of environmental management, 
not so much because of its centrality, but because of the number of documents and the number of citations to the papers (Table 6).

In terms of CSR, during this period the most frequently cited publications were those of the following authors: Fulmer and Gelfand (2012) [80], 230 citations; Cronin et al. (2011) [86], 202; Mishra and Suar (2010) [87], 186; Dao Langella and Carbo (2011) [88], 163; and Bohdanowicz, Zientara, and Novotna (2011) [54] with 118 citations. The topics discussed have been related, among others, to the importance of trust at all levels of the organizations and therefore in the CSR and HRM; the use of green strategies, especially in marketing and their connection to HR; and the company's overall strategy.

With respect to Commitment, the five most cited authors have been Tymon, Stump, and Doh, (2010) [89], 88 citations; Ben Brik, Rettab, and Mellahi (2011) [90], 65; Mueller et al. (2012) [91], 58; Hofman and Newman (2014) [92], 57; and Shen and Jiuhua Zhu (2011) [93], with 56 citations. The issues addressed in the research of these authors are CSR with topics related to talent exploration and intrinsic rewards, market orientation and performance, the effects of CSR on employee engagement, the moderating role of collectivism and masculinity on the impact of CSR on organizational engagement, or the effects of socially responsible HRM on employee organizational engagement.

Among the most cited authors of the Competitive-Advantage cluster are Cronin et al. (2011) [86], 202 citations; Reimann et al. (2012) [94], 55 citations; Wong and Wong (2014) [95], 37 citations; Shen (2011) [96], 35 citations; and Pless, Maak, and Stahl (2012) [56] with 32 citations. Its topics deal with green marketing strategies, how multinationals manage CSR according to the country where they are located, the importance of using the LEAN method in conjunction with HRM to achieve operations management in a sustainable way, the analysis of SR-HRM from an international perspective, or the promotion of CSR and sustainable development through HR development, for example through employee training or sending them to NGOs.

Finally, in relation to Environmental-Management, the five most cited authors are Mishra and Suar (2010) [87], 186 citations; Dao, Langella, and Carbo (2011) [88], 163; Bohdanowicz, Zientara, and Novotna (2011) [54], 118; Ben Brik, Rettab, and Mellahi (2011) [90], 65; and Wagner (2013) [57] with 52 citations. Many of them also lead the CSR and Commitment clusters. Themes are about the influence of CSR on performance, examining the role of information technology in sustainability beyond the reduction of energy consumption, the relationship of environmental performance to CSR and the close links to HR management, CSR and its impact or market orientation, or analyzing whether the benefits arising for HRM from environmental management activities drive the implementation of the environmental management system.

Table 6. Cluster period 2010-2014.

\begin{tabular}{|c|c|c|c|c|c|c|c|}
\hline Name & Centrality & Centrality Range & Density & Density Range & Documents & Citations & H-Index \\
\hline Commitment & 153.63 & 0.89 & 31.72 & 0.67 & 13 & 432 & 9 \\
\hline Model & 129.92 & 0.67 & 11.77 & 0.22 & 11 & 366 & 8 \\
\hline Environmental-Management & 125.60 & 0.56 & 19.56 & 0.33 & 12 & 696 & 9 \\
\hline Internationalization & 107.13 & 0.44 & 52.99 & 0.78 & 8 & 533 & 8 \\
\hline Market & 42.60 & 0.11 & 5.36 & 0.11 & 4 & 154 & 4 \\
\hline
\end{tabular}

Source: Prepared by the authors on the basis of SciMAT data.

Period 2015-2019

This last period followed the same line as the previous period. The increase in keywords (400) (Figure 3) and in particular in documents has been particularly high (from 78 to 212) (Table 4). This generates an enrichment of the theme. The clusters to be highlighted have been, as driving topics, CSR, Green-management and Job, with 206, 35, and 30 documents, respectively (Table 7). Stakeholders also stands out, which, although it is a basic issue, is relevant because of its centrality and the number of documents (39). 
With respect to the main subject, CSR, the most cited authors in this period have been Shen and Benson (2016) [66], 71 citations; Gond et al. (2017) [97], 70; Gallardo-Gallardo et al. (2015) [98], 56; Glavas, (2016) [99], 54; and Ehnert et al. (2016) [100] with 52 citations. In essence, the issues have been: the level of SR-HRM affect on employees' work behavior when CSR is a social norm, the psychological micro foundations of CSR, reviews of the literature on talent management examining the dominant theoretical frameworks (employee assessment or institutionalism) versus the alternative ones (knowledge management, career or social exchange), the study of synergies between CSR and organizational psychology, and comparative analyses of sustainability and HR reports with companies at an international level.

As for Green-Management, the authors with the most citations have been Dumont, Shen, and Deng (2017) [101], 42 citations; Guerci, Longoni, and Luzzini (2016) [67], 29; Hallam and Contreras (2016) [102], 20; Supanti, Butcher, and Fredline (2015) [103], 20; and Chang (2016) [104] with 19 citations. Topics have included the effects of Green HRM practices on employee environmental behavior in the workplace and their role in mediating stakeholders on environmental performance, literature reviews that clarify the relationship between lean and green management, analysis of the employer-employee relationship through CSR, as well as exploring the positive effects of corporate environmental commitment and Green Human Capital on green product innovation performance through the ability to comply with uncertain environmental regulations and environmentalism.

In the case of the subject of $J o b$, the five authors whose works have had the greatest number of citations have been Gond, et al. (2017) [97], 70 citations; Dumont, Shen, and Deng (2017) [101], 42; Newman et al. (2016) [105], 30; Kim et al. (2019) [106], 15; and finally Samara and Arenas (2017) [107] with 14 citations. Apart from issues that have been cited by clusters such as CSR or Green-Management, the influence of the three dimensions of SR-HRM, legal compliance with HRM, employee-oriented HRM, and general facilitation of CSR on employee citizenship behavior in the organization (OCB) are examined; the possible improvement of the ecological behavior of employees and environmental performance through Green Human Resource Management is analyzed; and finally sustainability of the family business through the promotion of equity in the workplace between family and non-family workers is analyzed.

For our last cluster analyzed, Stakeholders, the five most cited authors are Attig et al. (2016) [108], 41 citations; Gupta, Briscoe, and Hambrick (2017) [109], 37; Guerci, Longoni, and Luzzini (2016) [67], 29; Zheng, Luo, and Maksimov (2015) [110], 29; and finally Esteban-Sanchez, De La Cuesta-González, and Paredes-Gázquez (2017) [111], 23 citations. The topics covered include the positive relationship between the internationalization of companies and the qualification of CSR, the introduction of the concept of political ideology to explain how the political beliefs of the organization's members shape corporate advances in CSR, the analysis of philanthropy and sustainability as two extreme forms of adopting CSR, and finally the impact that Corporate Social Performance (CSP) may have had on Corporate Financial Performance (CFP) in the banking industry due to the economic and financial crisis of 2008 is analyzed.

Table 7. Cluster period 2015-2019.

\begin{tabular}{|c|c|c|c|c|c|c|c|}
\hline Name & Centrality & Centrality Range & Density & Density Range & Documents & Citations & H-Index \\
\hline CSR & 313.77 & 1.00 & 66.80 & 1.00 & 206 & 1540 & 18 \\
\hline Stakeholders & 145.90 & 0.93 & 10.57 & 0.33 & 39 & 337 & 10 \\
\hline Green-Management & 143.49 & 0.87 & 19.51 & 0.73 & 35 & 311 & 16 \\
\hline Behavior & 117.86 & 0.73 & 4.72 & 0.07 & 15 & 73 & 5 \\
\hline Conceptual-Framework & 114.96 & 0.67 & 8.40 & 0.27 & 19 & 148 & 7 \\
\hline Drivers & 106.28 & 0.60 & 22.34 & 0.93 & 10 & 154 & 4 \\
\hline Exchange & 104.76 & 0.47 & 12.90 & 0.47 & 13 & 131 & 7 \\
\hline Satisfaction & 101.39 & 0.40 & 13.40 & 0.53 & 27 & 278 & 9 \\
\hline Capabilities & 91.06 & 0.33 & 20.34 & 0.80 & 10 & 106 & 6 \\
\hline Diversity & 90.59 & 0.27 & 14.16 & 0.67 & 14 & 120 & 5 \\
\hline Cross & 89.15 & 0.20 & 20.78 & 0.87 & 11 & 131 & 5 \\
\hline Fuzzy & 32.79 & 0.13 & 12.00 & 0.40 & 3 & 28 & 2 \\
\hline
\end{tabular}

Source: Prepared by the authors on the basis of SciMAT data. 


\subsubsection{Thematic Networks}

In the period 1993-2009, although CSR and HRM with 23 and 13 documents, respectively, were the most published, Business-Ethics with 4 documents, due to its centrality, gave its name to the main cluster (Figure 5). The research of this cluster had to do with works related, in addition to the previous topics, with organizations and corporate or corporate social performance, financial-performance, behavior, small and medium enterprises (SME) or culture among others.

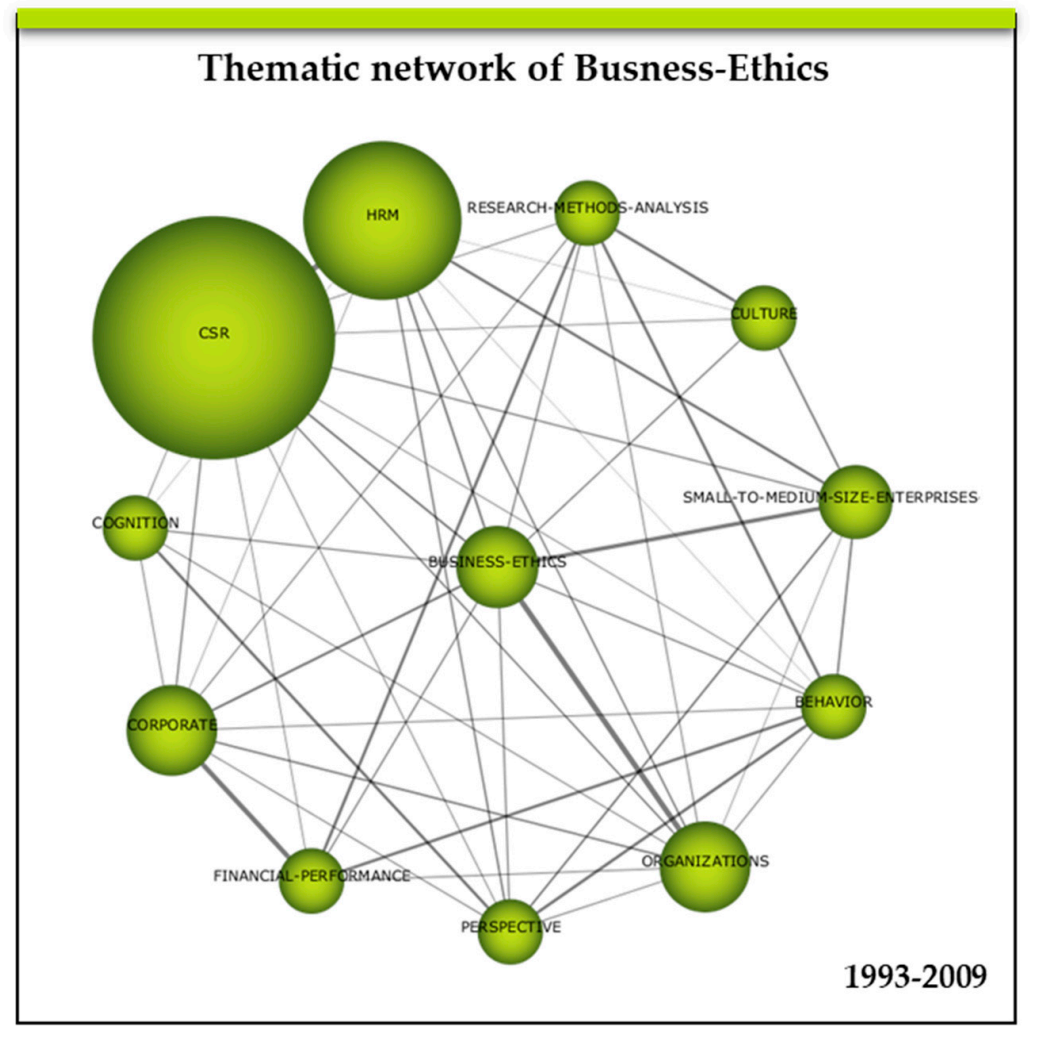

Figure 5. Thematic network of the main cluster 1993-2009. Source: Prepared by the authors on the basis of SciMAT data.

In the period 2010-2014, it is CSR that takes the greatest centrality, passing Business-Ethics to form part of the network with a smaller presence. As for the number of CSR and HRM documents, they again contain the largest number of publications, 71 and 52, respectively. New topics are incorporated into this cluster such as performance, business, employees, impact, firm-performance, or stakeholders (Figure 6). In the following period (2015-2019), stakeholders along with behavior - which disappears in this period-take special relevance forming their own clusters.

Finally, between the years 2015-2019, CSR is consolidated as the main driving theme and at the same time leads a network that is becoming increasingly dense. CSR and HRM continue to lead in the number of publications with 203 and 131, respectively. The most striking aspect of this period is the focus on issues related to performance, sustainability, and research-methods-analysis (Figure 7). In the case of the first one, the fact that its growth is substantial, being four times higher (from 24 to 96 documents), shows the clear interest aroused by its study. As for sustainability, which appears for the first time with a total of 86 publications, it maintains a relevant momentum with a clear projection that aims to be in the coming years an independent cluster with a vocation to define itself as a driving theme. With regard to research-methods-analysis, which contains work related to the different methods, indicators, or approaches to address research on CSR and HRM, it has evolved from the first period in which it had only 2 documents to 44 documents in the last period. 


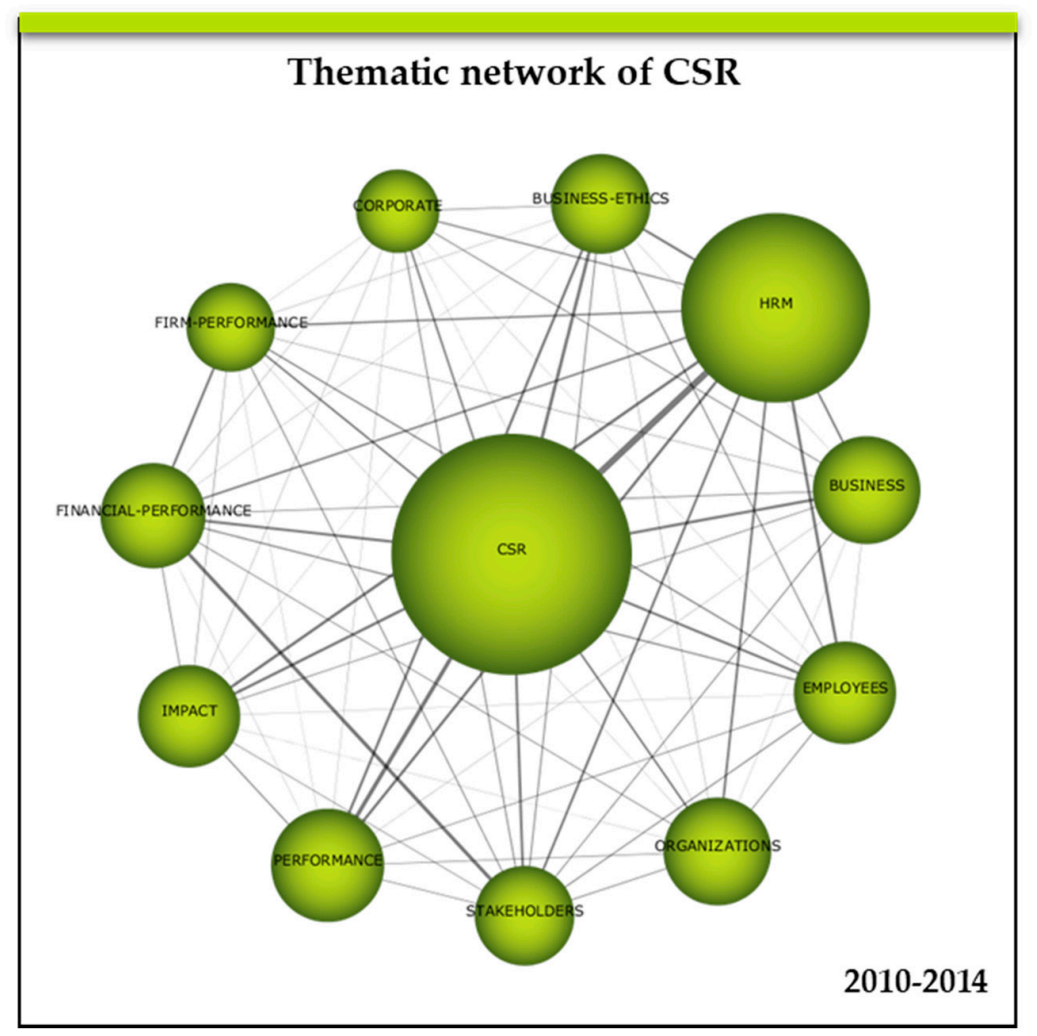

Figure 6. Thematic network of the main cluster 2010-2014. Source: Prepared by the authors on the basis of SciMAT data.

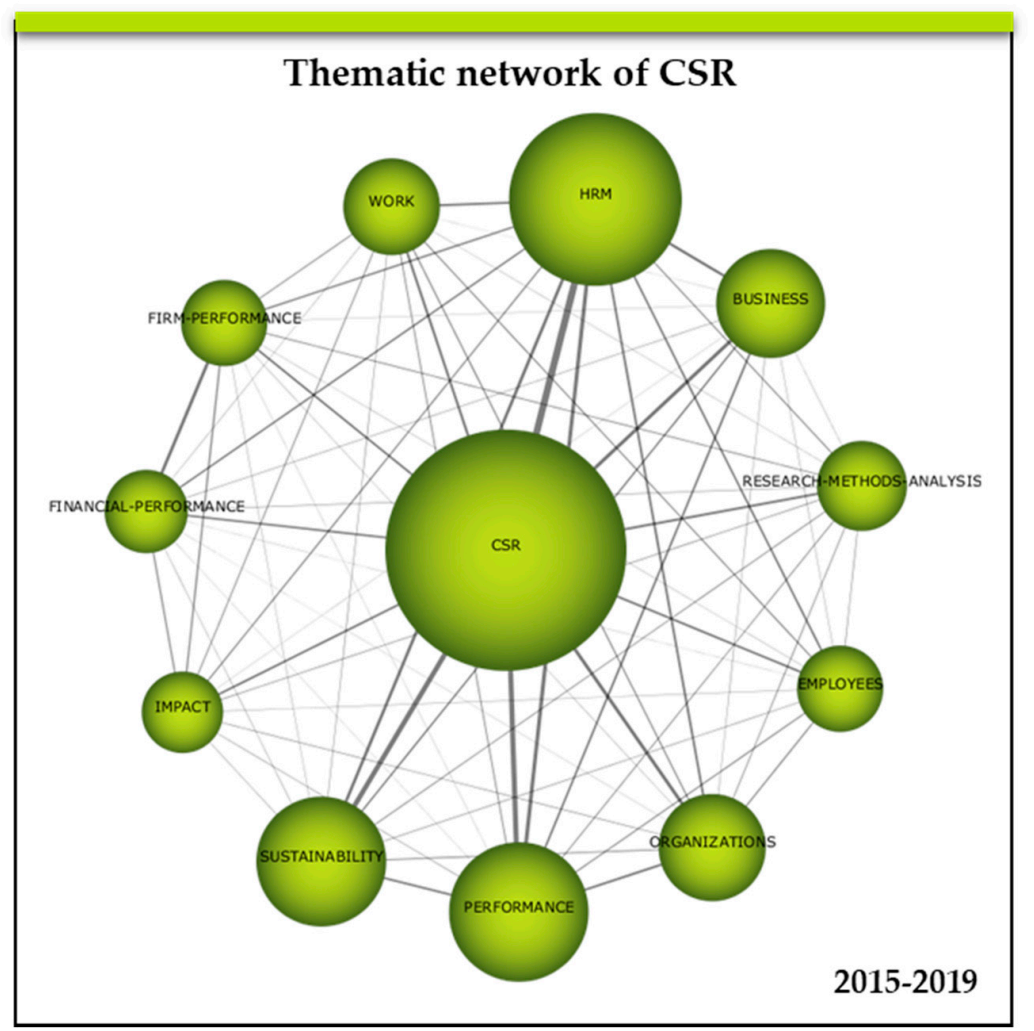

Figure 7. Thematic network of the main cluster 2015-2019. Source: Prepared by the authors on the basis of SciMAT data. 


\subsubsection{Relevant Issues in the Last Period (2015-2019)}

In addition to CSR, Green-Management and Stakeholders have stood out for their centrality in the last period thanks to the importance of their publications with a high level of citations and H-Index. In the case of the former, it is considered a driving theme and contains a total of 35 documents and 311 citations in this period, with an H-Index of 16. The latter is a basic theme that, in this last period, has formed its own cluster, with a growing level of publications (from 19 in the previous period to 35 in this period) and a high number of citations (337), which is expected to become a driving theme in the coming years (Table 7) (Appendix A). Both themes are in full growth and have a high level of travel yet to be explored.

Green-Management (Figure 8) is related to issues such as Environmental-management where research is linked to environmental performance and sustainability or pro-environmental strategies and behavior. Another topic that has considerable weight in the thematic network is Green-human-resource-management in which it is linked to other topics such as Operations-management, Knowledge-management, green supply chain management, or change management for sustainability. One of the contexts where Green-Management has been most studied is the tourism industry.

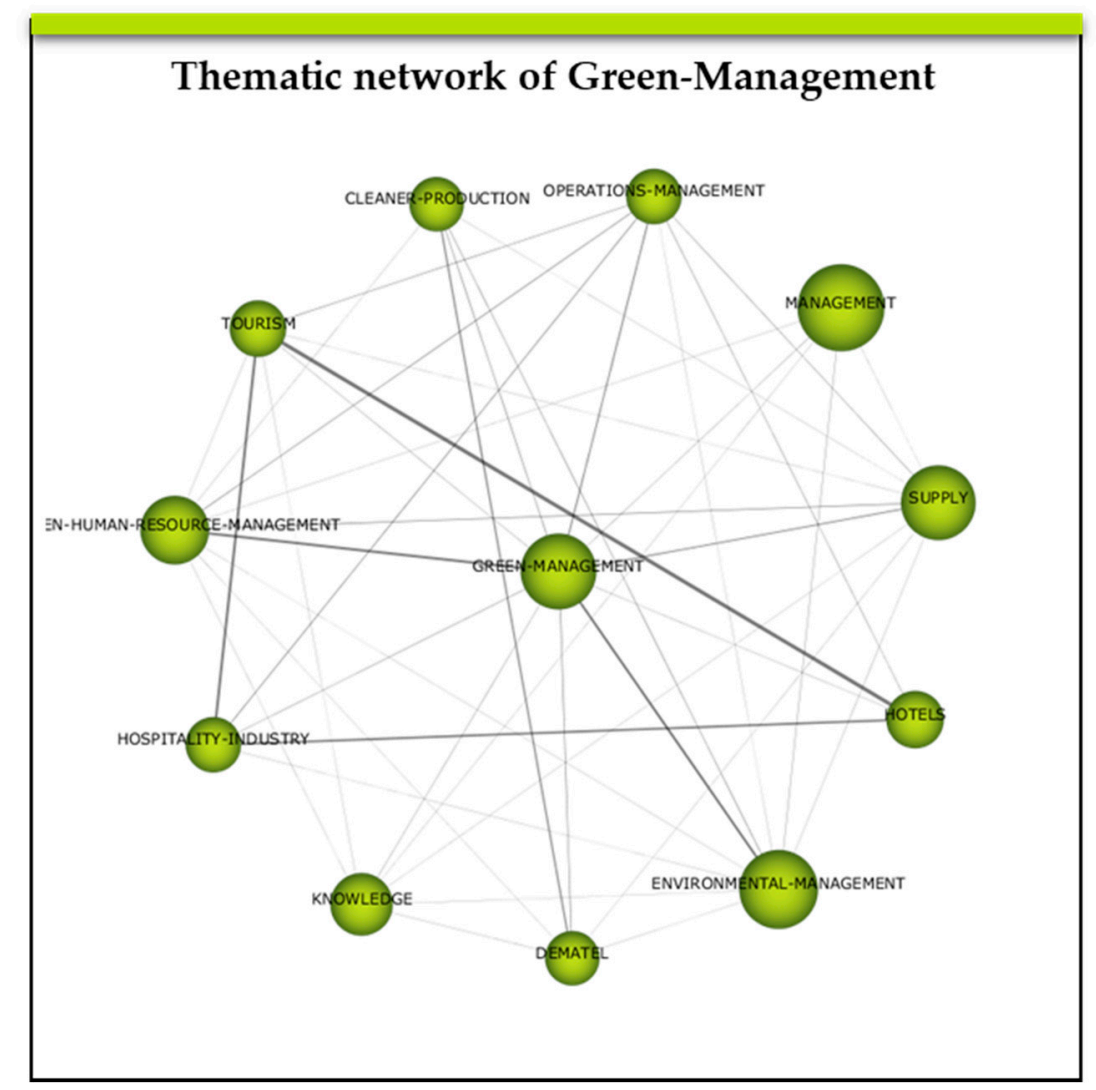

Figure 8. Thematic network of Green-Management. Source: Prepared by the authors on the basis of SciMAT data.

As for the Stakeholders Network (Figure 9), although all the issues are closely related, three ideas seem to be emerging, all of them under the Agency-Theory paradigm which could explain the increased interest in promoting Corporate Social Responsibility in business organizations by stakeholders. First, a subnet appears in which the concepts Corporate and its variants Corporate-governance, Social-performance or Corporate-citizenship are related to Framework and the consequent effect of Environmental-performance. A second idea is woven into the publications that investigate the issues related to Shareholders-Shareholders-value and Strategy or strategic-flexibility. And the third 
sub-network narrows under the themes Competitive-advantage and Turnover, which are, in turn, related to Strategy and Environmental-performance.

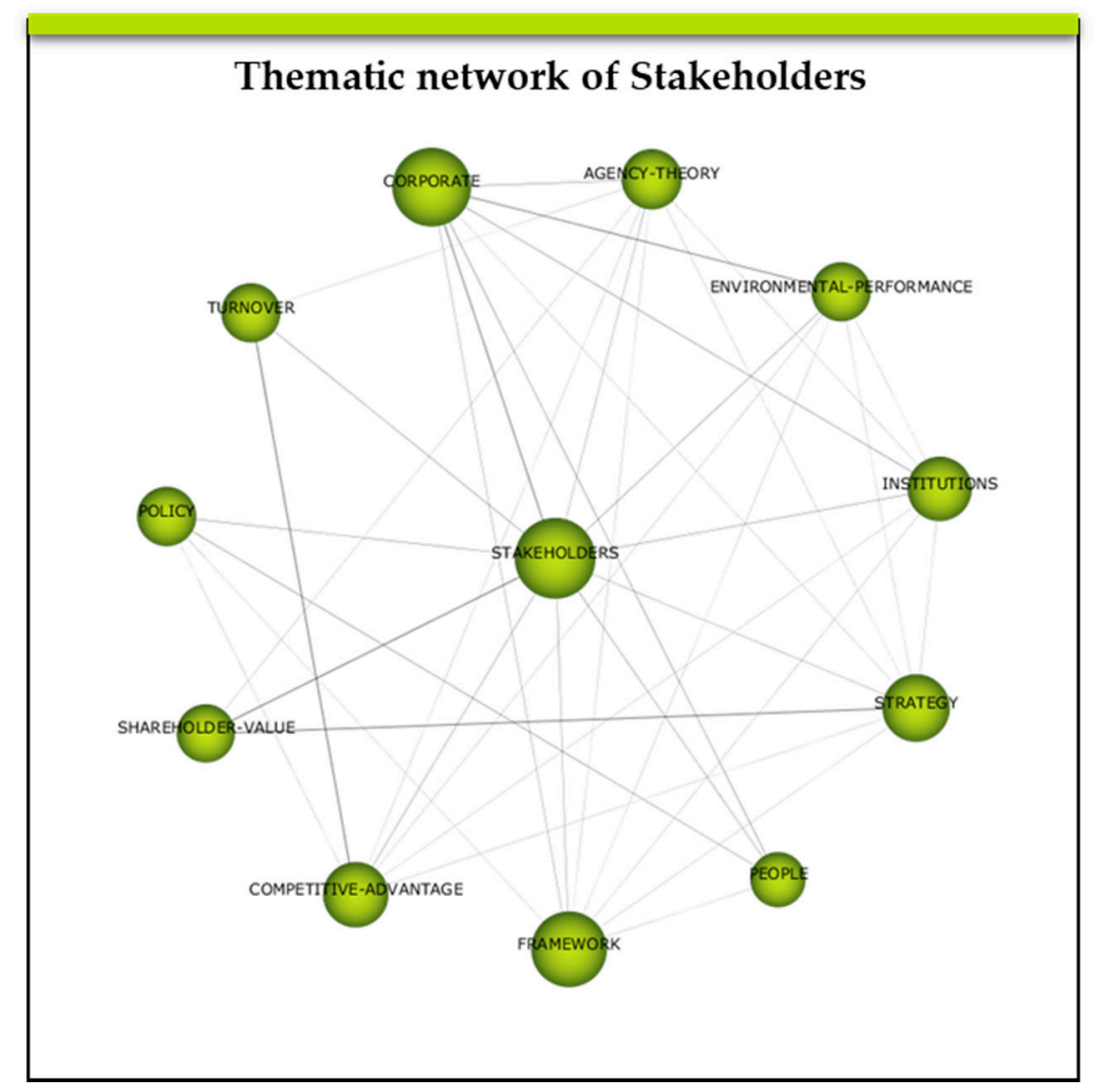

Figure 9. Thematic network of Stakeholders. Source: Prepared by the authors on the basis of SciMAT data.

In this last period, in addition to CSR and Green-Management, issues related to Job, (commitment or transformational-leadership or recruitment, among others), and Drivers (top-management, change-agent, challenges, talent, or critical success factor, among others) have been part of the driving issues. We must also refer to emerging issues such as Exchange, whose work has had to do with socialization, justice, equality, trust or emotions and, finally, a peripheral issue that is also interesting to note, Satisfaction, which has been investigated along with other issues such as business-ethics, flexibility, leadership, identity or individualism, among others.

\section{Conclusions}

Corporate Social Responsibility (CSR) and Human Resource Management (HRM) have evolved and interacted over time, but both are described and analyzed from different perspectives. The progress of research in this scientific field has made them related, because of their ecological foundations, but also economic and social, although not without controversy, with sustainability. The implementation of CSR in business organizations and the interconnection with all its subsystems, in particular with $\mathrm{HR}$, has awakened scientific interest, causing literary production that interrelates CSR and HRM to experience an unprecedented boom. More than $67 \%$ of all research has taken place in the last five years, but the potential, development, and measurement of both concepts has not been sufficiently explored. Therefore, the aim of this work is to shed light on the scientific production trends of these two concepts in a related way, and to give visibility to the lines of research that try to explain from all possible perspectives and approaches the theoretical and practical effects on sustainability produced by the implementation of CSR-sensitive policies and their integration into HRM. 
From the results of the bibliometric analysis, it can be seen that although its evolution has experienced a notable increase, this subject has a short history. The first article appeared in 1993, published by Anderson, in the Journal of Business Ethics [42], which is ultimately the most prolific journal, with $12.1 \%$ of the entire sample investigated. In the first period 1993-2009, only 24 documents were published, 7.6\% of all literary production. In the following period, between 2010 and 2014, 78 documents (36.4\%) are published and, between 2015 and 2019, 212 publications.

From what was analyzed in the first period, it is evident that CSR and HRM, even though they are the most mentioned topics in the research, are not sufficiently related to other topics, and Business-ethics occupied the greatest centrality in all the literature of the moment. There is a demand for more information regarding the CSR in relation to the environment, safety, and HR. The topics that were investigated together with Business-ethics were related to corporate, financial-performance, culture, or behavior, among others.

Between 2010 and 2014, CSR leads the way in centrality, being the main driving theme together with Commitment, Competitive-Advantage. Environmental Management is a basic topic that gets special relevance. During this period there is a certain sensitivity to the effects of SR-HRM on the organizational commitment of employees, the promotion of CSR and sustainable development through HR development, or the relationship of environmental performance with CSR and the close links with HR management. Performance, employees, impact, firm-performance, or stakeholders are issues that are closely related in this period together with CSR and HRM.

In the last period there has been an unprecedented increase in CSR and HRM, which means that their quantitative and qualitative enrichment has led to a multitude of adjacent lines of research. CSR maintains leadership of centrality. The most relevant topics are: Green-management, Job and Drivers (driving topics), Stakeholders (basic topic), Satisfaction (peripheral topic), and Exchange (emerging topic). In this period, the most striking thing in the CSR thematic network is the incorporation for the first time of sustainability, with a very high level of production and, performance and research-methods-analysis with a special evolution from previous periods. Green-management is related to topics such as Environmental-management, Green-human-resource-management, Green supply chain management, or Change management for sustainability. As for Job, its network relates issues such as commitment or transformational-leadership. Drivers are related to topics such as top-management, change-agent, challenges, talent, or critical success factor, among others. Stakeholders, under the paradigm of Agency-Theory weaves different sub-networks related to Corporate, Shareholders-value, and Competitive-advantage. Satisfaction is related to Business-ethics, flexibility, leadership, identity, or individualism, among others. Finally, Exchange is related to socialization, justice, trust, or emotions.

In summary, this work has highlighted the high interest of the scientific community in recent years in CSR and HRM. It has contributed by identifying groups of topics that have recently developed a special interest, and that should continue to be explored in future research such as Green-Management, Stakeholders, Commitment, Competitive-Advantage, Satisfaction, Performance, Sustainability, or Research-methods-analysis, in order to respond to the demands that business organizations have in this respect and to help the total integration of the different approaches related to CSR and HRM.

Author Contributions: Conceptualization, J.H. and C.d.1.H.-R.; methodology, J.H. and C.d.1.H.-R.; software, J.H. and C.d.1.H.-R.; validation, J.H. and C.d.1.H.-R.; formal analysis, J.H. and C.d.1.H.-R.; investigation, J.H. and C.d.l.H.-R.; resources, J.H. and C.d.1.H.-R.; writing-original draft preparation, J.H. and C.d.1.H.-R.; writing-review and editing, J.H. and C.d.1.H.-R.; supervision, J.H. and C.d.1.H.-R.; project administration, J.H. and C.d.1.H.-R. All authors have read and agreed to the published version of the manuscript.

Funding: This research received no external funding.

Acknowledgments: We are very grateful to Manuel Cobo for his valuable comments regarding the SciMAT methodology.

Conflicts of Interest: The authors declare no conflict of interest. 


\section{Appendix A}

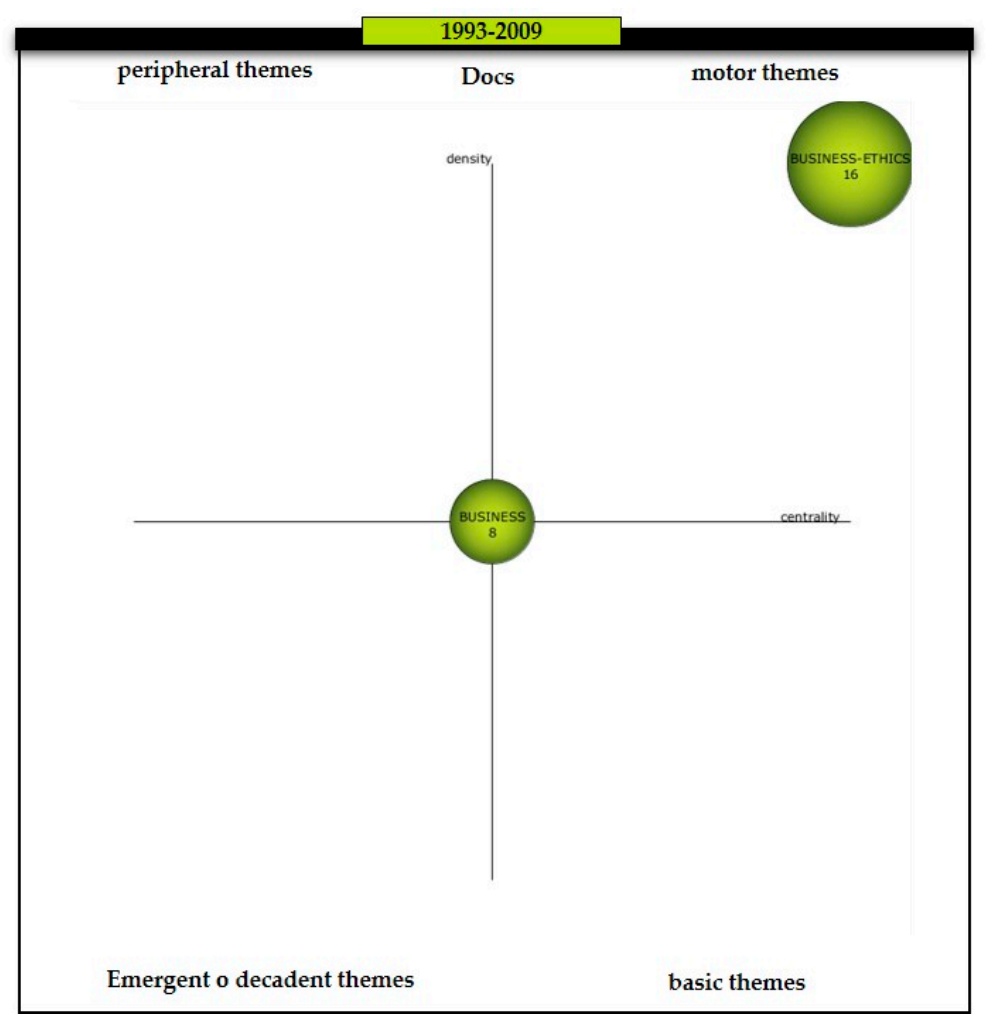

Figure A1. Strategic map of the period 1993-2009. Source: Prepared by the authors on the basis of SciMAT data.

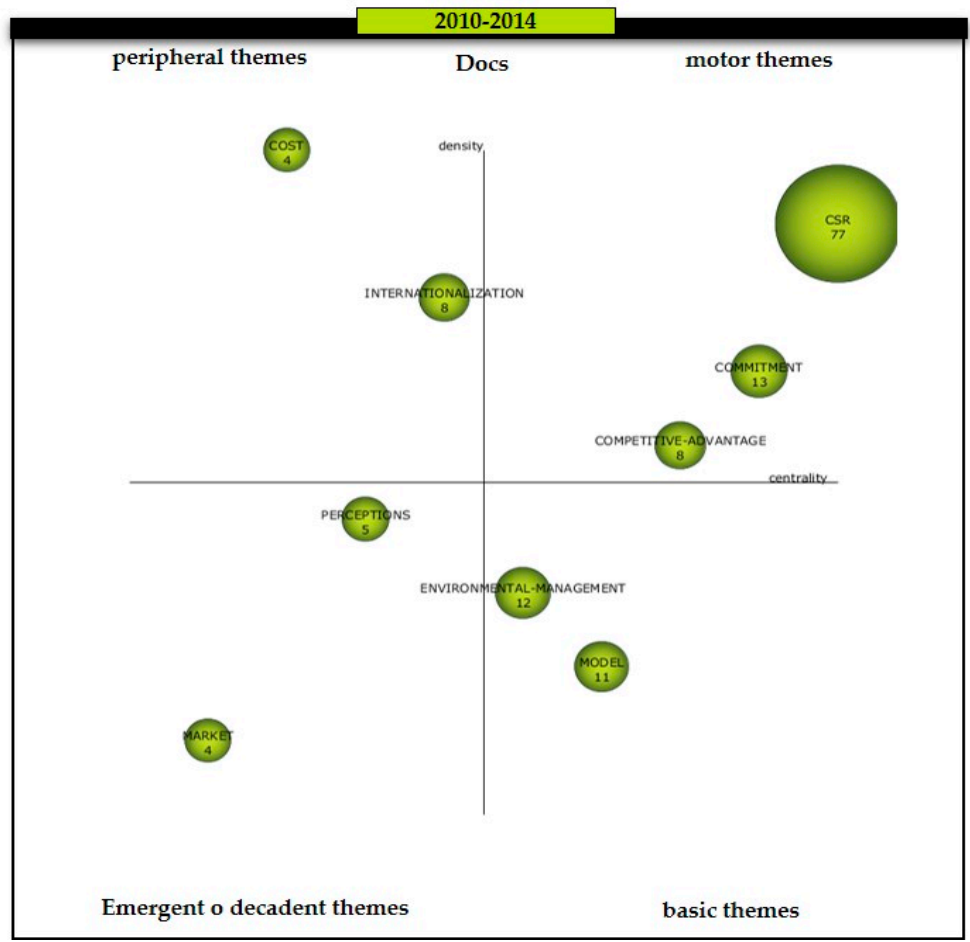

Figure A2. Strategic map of the period 2010-2014. Source: Prepared by the authors on the basis of SciMAT data. 


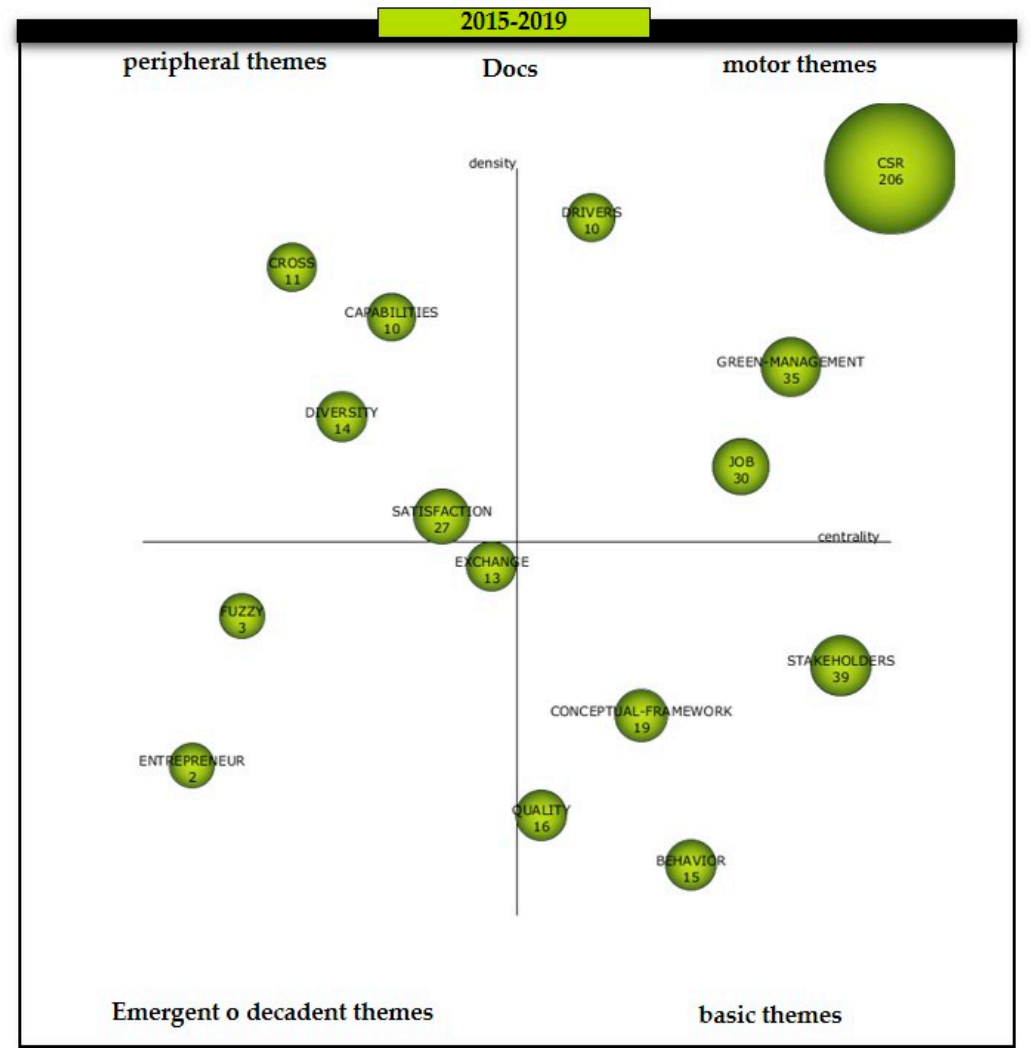

Figure A3. Strategic map of the period 2015-2019. Source: Prepared by the authors on the basis of SciMAT data.

\section{References}

1. Denisi, A.; Wilson, M.; Biteman, J. Research and practice in HRM: A historical perspective. Hum. Resour. Manag. Rev. 2014, 24, 219-231. [CrossRef]

2. Amaeshi, K.M.; Adi, B. Reconstructing the corporate social responsibility construct in Utlish. Bus. Ethics A Eur. Rev. 2007, 16, 3-18. [CrossRef]

3. Whitehouse, L. Corporate social responsibility as citizenship and compliance. J. Corp. Citizsh. 2003, 85-98. [CrossRef]

4. Spence, L. CSR and Small Business in a European Policy Context: The Five "C"s of CSR and Small Business Research Agenda 2007. Bus. Soc. Rev. 2007, 112, 533-552. [CrossRef]

5. Carroll, A. Corporate Social Responsibility: Evolution of a Definitional Construct. Bus. Soc. 1999, 38, $268-295$. [CrossRef]

6. Matten, D.; Moon, J. "Implicit" and "Explicit" CSR: A Conceptual Framework for a Comparative Understanding of Corporate Social Responsibility. Acad. Manag. Rev. 2008, 33, 404-424. [CrossRef]

7. Dahlsrud, A. How corporate social responsibility is defined: An analysis of 37 definitions. Corp. Soc. Responsib. Environ. Manag. 2008, 15, 1-13. [CrossRef]

8. Van Marrewijk, M. Concepts and Definitions of CSR and Corporate Sustainability: Between Agency and Communion. J. Bus. Ethics 2003, 44, 95-105. [CrossRef]

9. Carroll, A.B. A three-dimensional conceptual model of corporate performance. Acad. Manag. Rev. 1979, 4, 497-505. [CrossRef]

10. De Stefano, F.; Bagdadli, S.; Camuffo, A. The HR role in corporate social responsibility and sustainability: A boundary-shifting literature review. Hum. Resour. Manag. 2018, 57, 549-566. [CrossRef]

11. Kaufman, B. The historical development of American HRM broadly viewed. Hum. Resour. Manag. Rev. 2014, 24, 196-218. [CrossRef]

12. Greenwood, M. Ethical Analyses of HRM: A Review and Research Agenda. J. Bus. Ethics 2013, 114, 355-366. [CrossRef] 
13. Alvesson, M. Critical perspectives on strategic HRM. In The Routledge Companion to Strategic Human Resource Management; Storey, J., Wright, P.M., Ulrich, D., Eds.; Routledge: London, UK, 2009; pp. 52-67.

14. Dubois, P.; Alan Fox. Beyond contract: Work, power and trust relations, 1974. Sociol. Trav. 1974, 16, 331-333.

15. Burrell, G.; Morgan, G. Elements of the sociology of corporate life. In Sociological Paradigms and Organisational Analysis, 1st ed.; 3rd repr.; Gower: Aldershot, UK, 1985.

16. Kamoche, K. Juman resource management: A multiparadigmatic analysis. Pers. Rev. 1991, 20, 3-14. [CrossRef]

17. Managing Human Assets; Beer, M.; Spector, B.; Lawrence, P.R.; Quinn Mills, D.; Walton, R.E. (Eds.) The Free Press: New York, NY, USA, 1984. [CrossRef]

18. Watson, T. Critical social science, pragmatism and the realities of HRM. Int. J. Hum. Resour. Manag. 2010, 21, 915-931. [CrossRef]

19. Mueller, F.; Carter, C. The "HRM project" and managerialism. J. Organ. Chang. Manag. 2005, 18, 369-382. [CrossRef]

20. Starik, M.; Rands, G. Weaving An Integrated Web: Multilevel and Multisystem Perspectives of Ecologically Sustainable Organisations. Acad. Manag. Rev. 1995, 20, 908-935. [CrossRef]

21. WECD. Our Common Future; Oxford University Press: Oxford, UK; New York, NY, USA, 1987.

22. Bansal, P. Evolving sustainably: A longitudinal study of corporate sustainable development. Strateg. Manag. J. 2005, 26, 197-218. [CrossRef]

23. Banerjee, S. Who Sustains Whose Development? Sustainable Development and the Reinvention of Nature. Organ. Stud. 2003, 24, 143-180. [CrossRef]

24. Nyberg, D.; Wright, C. Corporate corruption of the environment: Sustainability as a process of compromise. Br. J. Sociol. 2013, 64, 405-424. [CrossRef]

25. Boudreau, J.; Ramstad, P. Talentship, talent segmentation, and sustainability: A new HR decision science paradigm for a new strategy definition. Hum. Resour. Manag. 2005, 44, 129-136. [CrossRef]

26. Lam, H.; Khare, A. HR's crucial role for successful CSR. J. Int. Bus. Ethics 2010, 3, 3-15.

27. Gond, J.; Igalens, J.; Swaen, V.; El Akremi, A. The Human Resources Contribution to Responsible Leadership: An Exploration of the CSR-HR Interface. J. Bus. Ethics 2011, 98 (Suppl. 1), 115-132. [CrossRef]

28. Montiel, I. Corporate Social Responsibility and Corporate Sustainability: Separate Pasts, Common Futures. Organ. Environ. 2008, 21, 245-269. [CrossRef]

29. Beer, M.; Boselie, P.; Brewster, C. Back to the Future: Implications for the Field of HRM of the Multistakeholder Perspective Proposed 30 Years Ago. Hum. Resour. Manag. 2015, 54, 427-438. [CrossRef]

30. Porter, M.; Kramer, M.; Porter, M. The competitive advantage of corporate philanthropy. Harv. Bus. Rev. 2002, 80, 56-133.

31. Ehnert, I.; Harry, W.; Zink, K. Sustainability and Human Resource Management: Developing Sustainable Business Organisations, 1st ed.; Springer: Berlin/Heidelberg, Germany, 2014. [CrossRef]

32. Pfeffer, J. Building Sustainable Organisations: The Human Factor. Acad. Manag. Perspect. 2010, $24,34-45$. [CrossRef]

33. Spooner, K.; Kaine, S. Defining sustainability and human resource management. Int. Employ. Relat. Rev. 2010, 16, 70-81.

34. Ehnert, I. Paradox theory as a lens of theorising for sustainable HRM. In Sustainable Human Resource Management; Physica-Verlag HD: Heidelberg, Germany, 2009; pp. 123-162. [CrossRef]

35. Guerci, M.; Pedrini, M. The consensus between Italian HR and sustainability managers on HR management for sustainability-driven change-Towards a "strong" HR management system. Int. J. Hum. Resour. Manag. 2014, 25, 1787-1814. [CrossRef]

36. Albort-Morant, G.; Ribeiro Soriano, D. A bibliometric analysis of international impact of business incubators. J. Bus. Res. 2016, 69, 1775-1779. [CrossRef]

37. Chen, G.; Xiao, L. Selecting publication keywords for domain analysis in bibliometrics: A comparison of three methods. J. Informetr. 2016, 10, 212-223. [CrossRef]

38. Rey-Martí, A.; Ribeiro Soriano, D.; Palacios Marqués, D. A bibliometric analysis of social entrepreneurship. J. Bus. Res. 2016, 69, 1651-1655. [CrossRef]

39. WOS Database Available from the Spanish Foundation for Science and Technology. FEYCT. Available online: https://www.recursoscientificos.fecyt.es/ (accessed on 5 October 2019). 
40. Cobo, M.; López-Herrera, A.; Herrera-Viedma, E.; Herrera, F. SciMAT: A new science mapping analysis software tool. J. Am. Soc. Inf. Sci. Technol. 2012, 63, 1609-1630. [CrossRef]

41. Cobo, M. SciMAT: Software Tool for the Analysis of the Evolution of Scientific Knowledge. Proposal for an Evaluation Methodology. Ph.D. Thesis, University of Granada, Granada, Spain, 2011.

42. Anderson, C. Corporate social responsibility and worker skills: An examination of corporate responses to work place illiteracy. J. Bus. Ethics 1993, 12, 281. [CrossRef]

43. Albinger, H.; Freeman, S. Corporate Social Performance and Attractiveness as an Employer to Different Job Seeking Populations. J. Bus. Ethics 2000, 28, 243-253. [CrossRef]

44. May Seitanidi, M. Intangible economy: How can investors deliver change in businesses? Manag. Decis. 2007, 45, 853-865. [CrossRef]

45. Olowu, B. Redesigning African civil service reforms. J. Mod. Afr. Stud. 1999, 37, 1-23. [CrossRef]

46. Frynas, J. The false developmental promise of Corporate Social Responsibility: Evidence from multinational oil companies. Int. Aff. 2005, 81, 581-598. [CrossRef]

47. Vuontisjärvi, T. Corporate Social Reporting in the European Context and Human Resource Disclosures: An Analysis of Finnish Companies. J. Bus. Ethics 2006, 69, 331-354. [CrossRef]

48. Mankelow, G. Social responsibility paradox of small business human resource management practices. Int. J. Hum. Resour. Manag. 2008, 19, 2171-2181. [CrossRef]

49. Waring, P.; Edwards, T. Socially Responsible Investment: Explaining its Uneven Development and Human Resource Management Consequences. Corp. Gov. Int. Rev. 2008, 16, 135-145. [CrossRef]

50. Wojtaszczyk, P. Promoting workplace health promotion in the concept for corporate social responsibility $(\mathrm{csr})^{*} /$ the role of workplace health promotion in the concept for corporate social responsibility. Occup. Med. 2008, 59, 255-261.

51. Fuentes-García, F.; Núñez-Tabales, J.; Veroz-Herradón, R. Applicability of Corporate Social Responsibility to Human Resources Management: Perspective from Spain. J. Bus. Ethics 2008, 82, 27-44. [CrossRef]

52. Hallin, A.; Gustavsson, T. Managing death-Corporate social responsibility and tragedy. Corp. Soc. Responsib. Environ. Manag. 2009, 16, 206-216. [CrossRef]

53. Preuss, L.; Haunschild, A.; Matten, D. The rise of CSR: Implications for HRM and employee representation. Int. J. Hum. Resour. Manag. 2009, 20, 953-973. [CrossRef]

54. Bohdanowicz, P.; Zientara, P.; Novotna, E. International hotel chains and environmental protection: An analysis of Hilton's we care! programme (Europe, 2006-2008). J. Sustain. Tour. 2011, 19, 797-816. [CrossRef]

55. Mason, C.; Simmons, J. Forward looking or looking unaffordable? Utilising academic perspectives on corporate social responsibility to assess the factors influencing its adoption by business. Bus. Ethics 2011, 20, 159-176. [CrossRef]

56. Pless, N.; Maak, T.; Stahl, G. Promoting corporate social responsibility and sustainable development through management development: What can be learned from international service learning programs? Hum. Resour. Manag. 2012, 51, 873-903. [CrossRef]

57. Wagner, M. “Green” human resource benefits: Do they matter as determinants of environmental management system implementation? J. Bus. Ethics 2013, 114, 443-456. [CrossRef]

58. Boyd, N.; Gessner, B. Human resource performance metrics: Methods and processes that demonstrate you care. Cross Cult. Manag. Int. J. 2013, 20, 251-273. [CrossRef]

59. Arnaud, S.; Wasieleski, D. Corporate Humanistic Responsibility: Social Performance Through Managerial Discretion of the HRM. J. Bus. Ethics 2014, 120, 313-334. [CrossRef]

60. Suriyankietkaew, S.; Avery, G. Sustainable Leadership Practices Driving Financial Performance: Empirical Evidence from Thai SMEs. Sustainability 2016, 8, 327. [CrossRef]

61. Longoni, A.; Cagliano, R. Human resource and customer benefits through sustainable operations. Int. J. Oper. Prod. Manag. 2016, 36, 1719-1740. [CrossRef]

62. Voegtlin, C.; Greenwood, M. Corporate social responsibility and human resource management: A systematic review and conceptual analysis. Hum. Resour. Manag. Rev. 2016, 26, 181-197. [CrossRef]

63. Wang, W.; Fu, Y.; Qiu, H.; Moore, J.; Wang, Z.; Wang, W. Corporate Social Responsibility and Employee Outcomes: A Moderated Mediation Model of Organisational Identification and Moral Identity. Front. Psychol. 2017, 8, 1906. [CrossRef]

64. Delmas, M.; Pekovic, S. Organisational Configurations for Sustainability and Employee Productivity: A Qualitative Comparative Analysis Approach. Bus. Soc. 2018, 57, 216-251. [CrossRef] 
65. Barrena-Martinez, J.; López-Fernández, M.; Romero-Fernández, P.M. The link between socially responsible human resource management and intellectual capital. Corp Soc. Resp. Environ. Manag. 2019, 26, 71-81. [CrossRef]

66. Shen, J.; Benson, J. When CSR Is a Social Norm: How Socially Responsible Human Resource Management Affects Employee Work Behavior. J. Manag. 2016, 42, 1723-1746. [CrossRef]

67. Guerci, M.; Longoni, A.; Luzzini, D. Translating stakeholder pressures into environmental performance-The mediating role of green HRM practices. Int. J. Hum. Resour. Manag. 2016, 27, 262-289. [CrossRef]

68. López-Fernández, M.; Romero-Fernández, P.M.; Aust, I. Socially Responsible Human Resource Management and Employee Perception: The Influence of Manager and Line Managers. Sustainability 2018, 10, 4614. [CrossRef]

69. Lee, M.; Kim, H. Exploring the Organisational Culture's Moderating Role of Effects of Corporate Social Responsibility (CSR) on Firm Performance: Focused on Corporate Contributions in Korea. Sustainability 2017, 9, 1883. [CrossRef]

70. Ciocirlan, C. Environmental Workplace Behaviors: Definition Matters. Organ. Environ. 2017, 30, 51-70. [CrossRef]

71. Stankevičiūtè, Ž.; Savanevičienè, A. Designing Sustainable HRM: The Core Characteristics of Emerging Field. Sustainability 2018, 10, 4798. [CrossRef]

72. Longoni, A.; Luzzini, D.; Guerci, M. Deploying Environmental Management Across Functions: The Relationship Between Green Human Resource Management and Green Supply Chain Management. J. Bus. Ethics 2018, 151, 1081-1095. [CrossRef]

73. Kainzbauer, A.; Rungruang, P. Science Mapping the Knowledge Base on Sustainable Human Resource Management, 1982-2019. Sustainability 2019, 11, 3938. [CrossRef]

74. Kucharčíková, A.; Mičiak, M. Human Capital Management in Transport Enterprises with the Acceptance of Sustainable Development in the Slovak Republic. Sustainability 2018, 10, 2530. [CrossRef]

75. Hussain, T.; Edgeman, R.; Eskildsen, J.; Shoukry, A.M.; Gani, S. Sustainable Enterprise Excellence: Attribute-Based Assessment Protocol. Sustainability 2018, 10, 4097. [CrossRef]

76. Bombiak, E.; Marciniuk-Kluska, A. Green Human Resource Management as a Tool for the Sustainable Development of Enterprises: Polish Young Company Experience. Sustainability 2018, 10, 1739. [CrossRef]

77. Järlström, M.; Saru, E.; Vanhala, S. Sustainable Human Resource Management with Salience of Stakeholders: A Top Management Perspective. J. Bus. Ethics 2018, 152, 703-724. [CrossRef]

78. Farooq, M.; Farooq, O.; Cheffi, W. How Do Employees Respond to the CSR Initiatives of their Organisations: Empirical Evidence from Developing Countries. Sustainability 2019, 11, 2646. [CrossRef]

79. Barrena-Martínez, J.; López-Fernández, M.; Márquez-Moreno, C.; Romero-Fernández, P. Corporate Social Responsibility in the Process of Attracting College Graduates. Corp. Soc. Responsib. Environ. Manag. 2015, 22, 408-423. [CrossRef]

80. Fulmer, C.; Gelfand, M. At What Level (and in Whom) We Trust: Trust Across Multiple Organisational Levels. J. Manag. 2012, 38, 1167-1230. [CrossRef]

81. Price, D.; Gürsey, S. Studies in scientometrics I: Transience and continuance in scientific authorship. Ci. Inform. $1975,4,27-40$.

82. Collins, D. The Quest to Improve the Human Condition: The First 1500 Articles Published in Journal of Business Ethics. J. Bus. Ethics 2000, 26, 1-73. [CrossRef]

83. Cornelius, N.; Todres, M.; Janjuha-Jivraj, S.; Woods, A.; Wallace, J. Corporate Social Responsibility and the Social Enterprise. J. Bus. Ethics 2008, 81, 355-370. [CrossRef]

84. Holder-Webb, L.; Cohen, J.; Nath, L.; Wood, D. The Supply of Corporate Social Responsibility Disclosures Among U.S. Firms. J. Bus. Ethics 2009, 84, 497-527. [CrossRef]

85. Bohdanowicz, P.; Zientara, P. Corporate Social Responsibility in Hospitality: Issues and Implications. A Case Study of Scandic. Scand. J. Hosp. Tour. 2008, 8, 271-293. [CrossRef]

86. Cronin, J.; Smith, J.; Gleim, M.; Ramirez, E.; Martinez, J. Green marketing strategies: An examination of stakeholders and the opportunities they present. J. Acad. Mark. Sci. 2011, 39, 158-174. [CrossRef]

87. Mishra, S.; Suar, D. Does Corporate Social Responsibility Influence Firm Performance of Indian Companies? J. Bus. Ethics 2010, 95, 571-601. [CrossRef]

88. Dao, V.; Langella, I.; Carbo, J. From green to sustainability information technology and an integrated sustainability framework. J. Strateg. Inf. Syst. Inc. Int. Inf. Syst. 2011, 20, 63-79. [CrossRef] 
89. Tymon, W.; Doh, J.; Stumpf, S. Exploring talent management in India: The neglected role of intrinsic rewards. J. World Bus. 2010, 45, 109-121. [CrossRef]

90. Ben Brik, A.; Rettab, B.; Mellahi, K. Market Orientation, Corporate Social Responsibility, and Business Performance. J. Bus. Ethics 2011, 99, 307-324. [CrossRef]

91. Mueller, K.; Hattrup, K.; Spiess, S.; Lin-Hi, N. The Effects of Corporate Social Responsibility on Employees' Affective Commitment: A Cross-Cultural Investigation. J. Appl. Psychol. 2012, 97, 1186-1200. [CrossRef] [PubMed]

92. Hofman, P.; Newman, A. The impact of perceived corporate social responsibility on organisational commitment and the moderating role of collectivism and masculinity: Evidence from China. Int. J. Hum. Resour. Manag. 2014, 25, 631-652. [CrossRef]

93. Shen, J.; Jiuhua Zhu, C. Effects of socially responsible human resource management on employee organisational commitment. Int. J. Hum. Resour. Manag. 2011, 22, 3020-3035. [CrossRef]

94. Reimann, F.; Ehrgott, M.; Kaufmann, L.; Carter, C. Local stakeholders and local legitimacy MNEs' social strategies in emerging economies. J. Int. Manag. 2012, 18, 1-17. [CrossRef]

95. Wong, W.; Wong, K. Synergizing an ecosphere of lean for sustainable operations. J. Clean. Prod. 2014, 85, 51-66. [CrossRef]

96. Shen, J. Developing the concept of socially responsible international human resource management. Int. J. Hum. Resour. Manag. 2011, 22, 1351-1363. [CrossRef]

97. Gond, J.; El Akremi, A.; Swaen, V.; Babu, N. The psychological microfoundations of corporate social responsibility: A person-centric systematic review. J. Organ. Behav. 2017, 38, 225-246. [CrossRef]

98. Gallardo-Gallardo, E.; Nijs, S.; Dries, N.; Gallo, P. Towards an understanding of talent management as a phenomenon-driven field using bibliometric and content analysis. Hum. Resour. Manag. Rev. 2015. [CrossRef]

99. Glavas, A.; Glavas, A. Corporate Social Responsibility and Organisational Psychology: An Integrative Review. Front. Psychol. 2016, 7, 144. [CrossRef] [PubMed]

100. Ehnert, I.; Parsa, S.; Roper, I.; Wagner, M.; Muller-Camen, M. Reporting on sustainability and HRM: A comparative study of sustainability reporting practices by the world's largest companies. Int. J. Hum. Resour. Manag. 2016, 27. [CrossRef]

101. Dumont, J.; Shen, J.; Deng, X. Effects of green HRM practices on employee workplace green behavior the role of psychological green climate and employee green values. Hum. Resour. Manag. 2017, 56, 613-627. [CrossRef]

102. Hallam, C.; Contreras, C. Integrating lean and green management. Manag. Decis. 2016, 54, $2157-2187$. [CrossRef]

103. Supanti, D.; Butcher, K.; Fredline, L. Enhancing the employer-employee relationship through corporate social responsibility (CSR) engagement. Int. J. Contemp. Hosp. Manag. 2015, 27, 1479-1498. [CrossRef]

104. Chang, C. The Determinants of Green Product Innovation Performance. Corp. Soc. Responsib. Environ. Manag. 2016, 23, 65-76. [CrossRef]

105. Newman, A.; Miao, Q.; Hofman, P.; Zhu, C. The impact of socially responsible human resource management on employees' organisational citizenship behaviour: The mediating role of organisational identification. Int. J. Hum. Resour. Manag. 2016, 27, 440-455. [CrossRef]

106. Kim, Y.; Kim, W.; Choi, H.; Phetvaroon, K. The effect of green human resource management on hotel employees' eco-friendly behavior and environmental performance. Int. J. Hosp. Manag. 2019, 76, 83-93. [CrossRef]

107. Samara, G.; Arenas, D. Practicing fairness in the family business workplace. Bus. Horiz. 2017, 60, 647-655. [CrossRef]

108. Attig, N.; Boubakri, N.; El Ghoul, S.; Guedhami, O. Firm Internationalization and Corporate Social Responsibility. J. Bus. Ethics 2016, 134, 171-197. [CrossRef]

109. Gupta, A.; Briscoe, F.; Hambrick, D. Red, blue, and purple firms: Organisational political ideology and corporate social responsibility. Strateg. Manag. J. 2017, 38, 1018-1040. [CrossRef] 
110. Zheng, Q.; Luo, Y.; Maksimov, V. Achieving legitimacy through corporate social responsibility: The case of emerging economy firms. J. World Bus. 2015, 50, 389-403. [CrossRef]

111. Esteban-Sanchez, P.; de La Cuesta-Gonzalez, M.; Paredes-Gazquez, J. Corporate social performance and its relation with corporate financial performance: International evidence in the banking industry. J. Clean. Prod. 2017, 162, 1102-1110. [CrossRef] 